Old Dominion University ODU Digital Commons

\title{
How Do The Trans-Pacific Economies Affect the USA? An Industrial Sector Approach
}

Takeshi Yagihashi

Old Dominion University

David D. Selover

Old Dominion University

Follow this and additional works at: https://digitalcommons.odu.edu/economics_facpubs

Part of the Business Intelligence Commons, E-Commerce Commons, International Business Commons, and the International Economics Commons

\section{Repository Citation}

Yagihashi, Takeshi and Selover, David D., "How Do The Trans-Pacific Economies Affect the USA? An Industrial Sector Approach" (2017). Economics Faculty Publications. 27.

https://digitalcommons.odu.edu/economics_facpubs/27

\section{Original Publication Citation}

Yagihashi, T., \& Selover, D. D. (2017). How do the Trans-Pacific economies affect the USA? An industrial sector approach. World Economy, 40(10), 2097-2124. doi:10.1111/twec.12471

This Article is brought to you for free and open access by the Department of Economics at ODU Digital Commons. It has been accepted for inclusion in Economics Faculty Publications by an authorized administrator of ODU Digital Commons. For more information, please contact

digitalcommons@odu.edu. 


\title{
How Do the Trans-Pacific Economies Affect the US?
}

\section{An Industrial Sector Approach}

June 5, 2016

\author{
Takeshi Yagihashi ${ }^{1}$ and David D. Selover ${ }^{2}$ \\ Department of Economics, Old Dominion University, Norfolk, VA
}

\begin{abstract}
:
This paper studies how the Trans-Pacific region affects the US economy in terms of business cycle transmission. We use a large dataset consisting of disaggregated sectoral industrial production indexes from selected countries in the region and employ a factoraugmented vector autoregression (FAVAR) approach to analyze the transmission of shocks in different industries. We find that a positive output shock in the entire Trans-Pacific region has positive effects on the majority of US manufacturing sectors. We also find that sectoral shocks in five sectors of the Trans-Pacific region have a large impact on the overall US economy. Three of the five sectors displayed strong same-sector responses relative to the overall response, suggesting that vertical production linkages might play a key role in the transmission of shocks. Our results highlight the importance of examining industrial sectors in studying the transmission of shocks in the Trans-Pacific region.
\end{abstract}

Key words: international business cycle transmission, sectoral transmission, production sharing, vertical specialization, factor-augmented vector autoregression

JEL classification: F41, F47, E32

\footnotetext{
${ }^{1}$ Department of Economics, Old Dominion University, 5115 Hampton Boulevard, Norfolk, VA 23529; phone 757-683-3512; email: tyagihas@odu.edu

${ }^{2}$ Department of Economics, Old Dominion University, 5115 Hampton Boulevard, Norfolk, VA 23529; phone 757-683-3541; email: dselover@odu.edu
} 


\section{INTRODUCTION}

Over the past three decades, the Trans-Pacific region has grown to become the main trading partner of the US. This region, made up of over 40 countries spread across Asia, Oceania, and the Americas, accounts for roughly two-thirds of the US trade volume. ${ }^{3}$ The fast growth in trade is due to various factors such as improved air transportation, increased use of computers in manufacturing, industrial agglomeration, and reduction in tariffs through free trade agreements in the Trans-Pacific region. ${ }^{4}$ The US administration has repeatedly made remarks about the economic importance of the region (e.g., "the pivot to Asia" and "America's Pacific Century") and is currently negotiating a regional trade agreement known as the Trans-Pacific Partnership (TPP). ${ }^{5}$ While being economically tied to the region is beneficial for the US economy in the long run (Petri and Plummer, 2012), there are also concerns among the public that this would subject the US economy to external shocks, such as the Asian financial crisis of the late 1990's and the disruptions of the Japanese Tohoku earthquake and tsunami of 2011. Thus, it is of prime interest to US policymakers to study how shocks in the Trans-Pacific region affect the US economy.

Our main purpose is to quantify how the US economy reacts at the aggregate and the sector levels to shocks from the Trans-Pacific region. Specifically, we are interested in answering the following series of questions: how does an overall Trans-Pacific shock affect the US? Which sectors in the US are particularly vulnerable? Which sectors in the Trans-Pacific region most strongly affect the US economy? Past studies have emphasized the positive role

\footnotetext{
${ }^{3}$ World Trade Organization, International Trade Statistics, 2012, Table I.12, page 31.

${ }^{4}$ See Helpman (2006), Hummels (2007), Williams (2013).

${ }^{5}$ For more information on the trade policy under current Obama administration, see Barfield (2009).
} 
that bilateral trade plays in business cycle transmission. ${ }^{6}$ However, as argued by Bems, Johnson and Yi (2010), bilateral trade does not determine exposure to a specific foreign country if there are vertical production linkages that involve several countries. Furthermore, Crosby (2003) finds that within the Asia-Pacific region, the standard measure of bilateral trade does not explain output co-movement.

There are several characteristics of the Trans-Pacific region that complicate our analysis. First, countries in this region differ not only in size and stage of development, but also in economic structure and how much they depend on foreign trade. Thus, selecting a few aggregate variables to represent this region is difficult. The second characteristic is that vertical production linkages are prominent in the region (Kimura, Takahashi, and Hayakawa, 2007). A leading example is seen in the auto industry, where car parts manufactured in Canada and Japan serve as essential inputs for automobile assembly in the US and Mexico. Similarly, in the electronics industry, semiconductors manufactured in Japan and Taiwan are used as components for machinery manufacturing in Malaysia and Thailand. Such vertical production linkages are expected to strengthen the transmission of business cycles across countries. ${ }^{7}$

To incorporate these characteristics in our analysis, we use a large panel of time series data consisting of disaggregated industrial production indexes. Our data cover sixteen major industrial sectors from nine countries in the Trans-Pacific region. We treat the Trans-Pacific region (excluding the US) as an independent regional unit by aggregating output across countries and/or sectors to study its impact on the US. We employ a factor-augmented vector

\footnotetext{
${ }^{6}$ See Frankel and Rose (1998), Baxter and Kouparitsas (2005).

${ }^{7}$ See Burstein, Kurz, and Tesar (2008), Ng (2010).
} 
autoregression (FAVAR) approach (Bernanke, Boivin, and Eliasz, 2005) to reduce the dimensions of our data and to simulate the transmission of shocks from the Trans-Pacific region to the US. FAVAR has two advantages compared with the traditional VAR. First, we can incorporate a broader set of information related to the unknown transmission mechanism by utilizing detailed sectoral data. Vasishtha and Maier (2013) claim that this aspect of FAVAR is particularly relevant when the business cycle transmission involves more than two countries. Second, the FAVAR analysis allows us to study the transmission of shocks in several dimensions, i.e. the effect of overall and sectoral shocks in the Trans-Pacific on the US economy for both overall and sectors.

There are several findings in this paper. First, while a positive shock in the overall TransPacific output generates positive responses in the US output for almost all sectors, the magnitude of the response differs substantially by sector. For example, the primary metals, machinery, electrical equipment, and computer/electronics sectors show large responses following TransPacific shocks, whereas the food, beverage/tobacco, and petroleum/coal sectors show almost no response. We find that the openness to trade and the durability of goods can explain part of the results. Second, we find that shocks in five Trans-Pacific sectors, i.e., plastics/rubber, primary metals, machinery, computer/electronics, and transportation equipment, result in large responses in the overall US output, indicating that these sectors are of particular importance to the US economy. The large responses of US output, particularly from shocks in relatively small sectors, such as plastics/rubber and primary metals, are surprising given that the past literature (e.g., Helg, Manasse, Monacelli, and Rovelli, 1995) has found that sectoral shocks have little overall effect. Third, to explore the possible reasons for the large effect, we examine the same-sector responses 
for the above five sectors. We find that for primary metals, computer/electronics, and transportation equipment, the same-sector response is larger than the overall response indicating that vertical production linkages within these sectors are relatively strong. Finally, our main results are robust to alternative specifications such as the inclusion of Chinese industrial production and oil prices, different numbers of factors and lags, different restrictions for the identification of shocks, and alternative method of aggregation.

This paper contributes to the literature in several ways. First, using a disaggregated sectoral dataset, we provide a coherent explanation on how exogenous shocks in the TransPacific region affect the US both in terms of the national economy and the individual sectors. While the international economics literature has long noted the importance of sectoral distinction in explaining the behavior of trade and output, the question of how the transmission of shocks from sector to sector compares to the transmission from sector to overall output remains relatively unexplored. Our results show that sectors that are not particularly large in size can generate large overall responses, highlighting the importance of vertical production linkages in the Trans-Pacific region.

Second, our paper adds to the literature that uses FAVAR to analyze the effects of major industrial country shocks on the US economy. ${ }^{8}$ We are not aware of any other study that examines business cycle transmission from the Trans-Pacific region to the US using a FAVAR approach. The study closest to ours is Bagliano and Morana (2009) who show that global output shocks, identified using macroeconomic variables of the US, Japan, UK, Canada, and twelve

\footnotetext{
${ }^{8}$ For studies that examine the effect on other countries see Liu, Mumtaz, and Theophilopoulou (2014), Mumtaz and Surico (2009), Vasishtha and Maier (2013).
} 
European countries, significantly affect the US GDP and prices. Boivin and Giannoni (2010) find that factors extracted from the macroeconomic variables of the fifteen main US trading partners Granger-cause US variables. Our work is unique in that we use sectoral output shocks to study the transmission mechanism, in addition to overall output shocks. In order to identify these shocks, we propose a novel approach that utilizes the information contained in the US input-output table.

The paper proceeds as follows. In Section 2 we review facts about the Trans-Pacific region, and Section 3 explains the econometric framework. Section 4 shows the main results. Section 5 conducts robustness checks, and Section 6 provides discussions of our results and conclusions.

\section{THE TRANS-PACIFIC ECONOMY}

(a) Background

The Trans-Pacific region generally refers to the group of countries spread across Asia, Oceania, and the Americas. In this paper, we specifically select eight countries (Canada, Japan, South Korea, Mexico, Malaysia, Peru, Thailand, and Taiwan) to represent the Trans-Pacific region and use the abbreviation "TP" to refer to this group of countries. The choice of countries is motivated by the ongoing discussion regarding the Trans-Pacific Partnership (TPP): Canada, Japan, Malaysia, Peru, and Mexico are current members of the TPP, and South Korea, Taiwan, 
and Thailand have expressed their interest in joining the partnership (Mercurio, 2014). ${ }^{9}$ Half of the countries are OECD members, while the remaining half are non-OECD developing countries. Jointly our sample countries represent about $86 \%$ of the total GDP in the entire Trans-Pacific region. $^{10}$

Studies find that vertical production linkage in the Trans-Pacific region is particularly strong, even compared to other highly integrated regions such as Europe. ${ }^{11}$ The vertical production linkage is prominent for several reasons. First, the Trans-Pacific region encompasses two regional trade agreements (NAFTA and ASEAN), with a large amount of trade and foreign direct investment conducted among the member countries. Canada and Mexico are strongly integrated to the US through intra-firm trade by multinational corporations ("production sharing"). ${ }^{12}$ The complementarity in the production process is likely to cause the shocks in the upstream sectors to be transmitted to the downstream sectors when goods cross the borders. Second, several Asian countries in the Trans-Pacific region specialize in a particular form of production that involves both imports and exports ("vertical specialization"). ${ }^{13}$ Burstein, Kurz, and Tesar (2008) and $\mathrm{Ng}$ (2010) find empirical evidence that the degree of production sharing and vertical specialization are both directly associated with business cycle co-movements. Finally, having a mix of OECD (developed) and non-OECD (developing) countries is likely to

\footnotetext{
${ }^{9}$ To guarantee a large enough sample size and a monthly sample frequency, we dropped some countries, such as Vietnam, Australia, and Chile, from the analysis.

${ }^{10}$ We did not include China and Russia in this calculation since both countries are not currently regarded as potential members of the TPP.

${ }^{11}$ See Amador and Cabral (2009), Ando (2006), Athukorala and Yamashita (2006), Daudin, Rifflart, and Schweisguth (2011), Johnson and Noguera (2012), Kimura, Takahashi, and Hayakawa (2007).

${ }^{12}$ Burstein, Kurz, and Tesar (2008) find that the intensity of production sharing (measured as the share of exports to the US in establishment total sales) of US-Canada and US-Mexico are $47 \%$ and 55\% respectively. These numbers are notably higher than other sample countries, e.g., US and 15 European countries combined (17\%) or US-Japan (2\%).

${ }^{13}$ According to Hummels, Ishii, and Yi (2001), South Korea and Taiwan are the highest in the degree of vertical specialization among the ten sample countries. Amador and Cabral (2009) show that Malaysia and Thailand are ranked $1^{\text {st }}$ and $9^{\text {th }}$ respectively in terms of vertical specialization activities among 72 sample countries.
} 
further increase the importance of vertical production linkages. As di Giovanni and Levchenko (2010) find, the vertical transmission channel explains a much larger portion of output comovement between an OECD and a non-OECD country compared to that between two OECD countries.

(b) The Data

Our output measures are monthly industrial production indexes, as used in other international business cycle analyses. ${ }^{14}$ Industrial production includes manufacturing, mining, and utilities, with manufacturing typically accounting for the largest shares (71\% for US in 2011). In 2008 , industrial production jointly accounted for $78 \%$ of global exports, far exceeding trade in services and agricultural items (Johnson, 2014). Studies have also noted that trade in manufactured goods is particularly sensitive to the business cycle, in contrast to trade in services and agricultural products that do not show much response (Bems, Johnson, and Yi, 2010, 2011).

Industrial production indexes measure production activity in gross terms. This is useful for studying the transmission of shocks across borders, since, according to Chen, Kondratowicz, and Yi (2005), roughly half of US imports is in intermediate goods. Industrial production indexes are recorded in the monthly frequency, which allows us to work with a large number of observations (Inklaar, Jong-A-Pin, and de Haan, 2008). This becomes particularly helpful when we compare impulse responses with a relatively short time horizon. For Canada, we use monthly GDP as the output measure because Canada does not publish monthly industrial production indexes at the sector level.

\footnotetext{
${ }^{14}$ See Canova, Ciccarelli, and Ortega (2007), Frankel and Rose (1998), Gerlach (1988), Inklaar, Jong-A-Pin, and de Haan (2008), and Rana (2007).
} 
We prepare the industrial production indexes for sixteen sectors based on the North American Industry Classification System (NAICS) at the three-digit level. These sectors include mining, food, beverage/tobacco, wood, paper, petroleum/coal, chemical, plastic/rubber, nonmetallic mineral, primary metals, fabricated metals, machinery, computer/electronics, electrical equipment and appliances, transportation equipment, and furniture. ${ }^{15}$ These sectors represent roughly $90 \%$ of the total industrial production in each of our sample countries. We choose to use a relatively high-level of aggregation to maintain consistency across countries which use different industry classification methods. ${ }^{16}$ Also, through the broader level of aggregation, our data become less subject to redefinition and discontinuation of the series (di Giovanni and Levchenko, 2010). According to the three-digit NAICS definition, conventional vertical production linkages are often captured by transactions within the same-sector rather than across different sectors. For example, car parts manufacturing such as engine and braking systems (NAICS code 3363) and the assembly of car parts into finished products (NAICS code 3361) are both categorized as transportation equipment manufacturing (NAICS code 336).

The sample period is $2001.01-2013.08(T=152)$, which covers the period since the Asian financial crisis. The relatively short sample period, which was dictated by data availability, ensures that the estimated model is relatively stable over time. To induce stationarity, we transform the original output measures in levels using 12-month log differencing. ${ }^{17}$ This

\footnotetext{
${ }^{15}$ We use the abbreviations Min, Food, Bev, Wood, Paper, Petro, Chem, Plas, Nmin, Pmet, Fmet, Mach, Comp, Eleq, Tran, and Furn, for the 16 sectors. We use the index $i=1, \ldots, 16$ corresponding to this order.

${ }^{16}$ For more information on the harmonization of sector definitions across countries, see the Data Appendix.

${ }^{17}$ In a separate experiment (not shown), we conducted Zivot-Andrews unit root tests (Andrews and Zivot, 1992) to the entire dataset and applied differencing to the variables that appeared to be borderline-stationary. The results did not change much.
} 
transformation helps to remove seasonal fluctuations for the output measures that are not readily available in seasonally adjusted form. ${ }^{18}$

To examine the effect of shocks from the entire TP region consisting of the eight preselected countries, we prepare weighted averages to represent the TP economy excluding the US. These weighted averages, both in the aggregate and by sectors, are constructed as follows,

$$
X_{i, t}^{T P}=\frac{\sum_{c=1}^{8} \alpha_{c}^{i} X_{i, t}^{c}}{\sum_{c=1}^{8} \alpha_{c}^{i}} \equiv \sum_{c=1}^{8} \omega_{c, i} X_{i, t}^{c}
$$

where $X_{i, t}^{T P}$ is the growth rate of the industrial production index of the TP region in each of the sixteen sectors plus the overall industrial production $(i=1, \ldots, 17) . X_{i, t}^{c}$ is sector $i$ 's industrial production index growth rate for the eight countries excluding the US $(c=1, \ldots, 8) . \alpha_{c}^{i}$ is the fixed weight defined as country c's GDP share within TP, multiplied by sector $i$ 's share of GDP of country $c$. According to the GDP figures obtained from the IMF World Economic Outlook database, the relative GDP shares of the selected eight countries remained relative stable over the sample period of 2000-2012. To reflect the most recent economic size of the countries, we take the average GDP shares during the last three years of our sample period (2010-2012) in the aggregation process. With these TP variables, our dataset consists of $N=164$ output series, which is sufficiently large to conduct a FAVAR analysis. Further details on the individual series are provided in Table A.1 in the appendix that is made available online. ${ }^{19}$

(c) Summary of the Data

\footnotetext{
${ }^{18}$ In addition, this transformation mitigates the large and sudden jumps in the data caused by mis-measurement or redefinition of sectors by government agencies.

${ }^{19}$ All appendix materials hereafter can be obtained from the author's website (www.sites.google.com/site/takeshiyagihashi/).
} 
Table 1 shows that the US is by far the largest country among the nine countries, with a GDP share close to $60 \%$ and a population share of almost $40 \%$. Japan is a dominant number two country with $17.9 \%$ of GDP, followed by Canada (6.7\%), South Korea (4.8\%), Mexico (4.6\%), and the rest (5.3\%). The trade-to-GDP ratios range widely from $23.3 \%$ for US to $138.7 \%$ for Malaysia.

Imbs (2004) argues that when the sectoral compositions of two countries are similar, their aggregate outputs tend to be correlated through common sector-specific shocks. Calderon, Chong, and Stein (2007) find similar empirical results from a large number of countries, and Crosby (2003), Kumakura (2006), and Shin and Wang (2003) confirm that the same also holds for different subsets of countries in the Asia-Pacific region. The sectoral composition of the TP countries is shown in the last column of Table 1. We see that Canada, Mexico, and Malaysia have relatively large weights on mining ( $8.3 \%-10.8 \%$ of GDP), whereas South Korea, Malaysia, and Taiwan instead specialize in computer/electronics production (4.5\%-16.7\% of GDP). To compare the sectoral composition of the TP and US, we calculate the sectoral GDP share of the individual countries using the GDP share among the TP countries as weights. As shown in Table A.2 in the online appendix, the GDP share of industrial production in the TP region is $23.8 \%$, whereas the same share for the US is $16.1 \%$. This means that the TP's GDP share of industrial production is roughly $50 \%$ higher than that of the US. The GDP share of individual TP sectors is also higher than that of the US by a similar magnitude, except for few sectors, such as primary metals ( $1.57 \%$ for TP, $0.30 \%$ for US) and electrical equipment ( $1.15 \%$ for TP, $0.38 \%$ for US). Thus we can conclude that the sectoral composition of the TP region is similar to that of the US, which may facilitate transmission of shocks through sectors. 
Figure 1 plots the growth rates of the overall and sectoral industrial production for the US and the TP. The US and TP output series behave similarly both in the aggregate and in the majority of the sectors. Table 2 reports means, standard deviations, and same-sector correlations of the US and TP output. Overall industrial production of the TP exhibits a larger standard deviation than that of the US (7.7\% for TP versus $4.9 \%$ for US), and the gap is pronounced for a few sectors, such as machinery and computer/electronics. The last column of Table 2 shows that same-sector correlations between the US and TP are all positive, but the correlations are quite different across sectors (compare 0.90 for primary metals versus 0.09 for petroleum/coal).

\section{ECONOMETRIC FRAMEWORK}

(a) Factor-Augmented Vector Autoregression (FAVAR)

FAVAR estimation involves two steps. First, we use principal component analysis to obtain the estimates of factors $\widehat{F}_{t} \equiv\left[\widehat{F}_{1, t}, \ldots, \widehat{F}_{K, t}\right]$. The observed output series $X_{t} \equiv\left[X_{1, t}, \ldots, X_{N, t}\right]$ are associated with the (unknown) factors as follows,

$$
X_{t}=\lambda F_{t}+e_{t}
$$

where $\lambda$ is the $N \times K$ matrix of factor loadings and $e_{t} \equiv\left[e_{1, t}, \ldots, e_{N, t}\right]$ is the idiosyncratic component of each series. Second, we estimate a VAR of the form,

$$
\left[\begin{array}{c}
\tilde{F}_{t} \\
X_{i, t}^{T P}
\end{array}\right]=\Phi(L)\left[\begin{array}{c}
\widetilde{F}_{t-1} \\
X_{i, t-1}^{T P}
\end{array}\right]+\widetilde{v}_{t}
$$


where $\widetilde{F}_{t}$ is the vector of estimated factors in which the direct dependence of $X_{i, t}^{T P}$ on $\hat{F}_{t}$ is removed (as explained below), $X_{i, t}^{T P}$ is the TP output series of interest and is treated as an additional observed factor. $\Phi(L)$ is a lag polynomial matrix of order $P$. The reduced form residuals $\widetilde{v}_{t} \equiv\left[\widetilde{v}_{F, t}, v_{i, t}^{T P}\right]^{\prime}$ in equation (2) can be further expressed as,

$$
\tilde{v}_{t}=\mathbf{R} \tilde{\varepsilon}_{t}
$$

where $\mathbf{R}$ is a square matrix and $\tilde{\varepsilon}_{t} \equiv\left[\tilde{\varepsilon}_{F, t}, \tilde{\varepsilon}_{i, t}^{T P}\right]^{\prime}$ is the structural shock recovered through the standard recursiveness assumption which states that the variables ordered later does not contemporaneously affect the variables ordered earlier within the vector $\left[\widetilde{F}_{t} X_{i, t}^{T P}\right]$.

In order to identify the TP shock $\tilde{\varepsilon}_{i, t}^{T P}$, we follow the method described in Bernanke, Boivin, and Eliasz (2005). First, we select a set of slow-moving variables from the dataset. By assumption, these slow-moving variables are not affected by $\tilde{\varepsilon}_{i, t}^{T P}$ contemporaneously. Second, principal component analysis is applied to these slow-moving variables to obtain factors $\hat{F}_{t}^{s} \equiv\left[\hat{F}_{1, t}^{s}, \ldots, \hat{F}_{K^{s}, t}^{s}\right]$. Finally, we regress $\hat{F}_{t}$ on $\hat{F}_{t}^{s}$ as

$$
\hat{F}_{t}=b_{0} \hat{F}_{t}^{s}+b_{1} X_{j, t}^{T P}+u_{t}
$$

and use the regression coefficient $b_{1}$ to remove the direct dependence of $X_{i, t}^{T P}$ on $\hat{F}_{t}$ as follows,

$$
\tilde{F}_{t}=\widehat{F}_{t}-b_{1} X_{i, t}^{T P}
$$

This procedure assures that $\tilde{\varepsilon}_{i, t}^{T P}$ is orthogonal to shocks on the principal components and can be treated as an independent structural shock in the FAVAR analysis. 


\section{(b) Model Specification}

We explain here how slow-moving variables are selected. For the overall TP output shock, we use the output series of the sectors that have the least amount of trade transactions between the US and the individual TP countries. According to the Europa World Plus trade statistics, these are beverage/tobacco, paper, nonmetallic minerals, and furniture sectors. To select slow-variables for the sectoral output shocks, we use the input-output table of the US as a proxy for the transaction between US sectors and TP sectors. Several studies, e.g., di Giovanni and Levchenko (2010) and Amador and Cabral (2009), have argued that the assumption of a uniform input-output production structure across countries is reasonable. ${ }^{20} \mathrm{We}$ convert an inputoutput use table obtained from the US Bureau of Economic Analysis (Use Table, Producer Prices in 2012) into spending shares and select the sectors with spending shares of less than one percent as our slow-moving variables. To illustrate how this works, consider the plastic/rubber sector. In 2012 , the sector sold $16.2 \%$ of its product to itself and $28.8 \%$ to the transportation equipment sector, whereas it sold only $0.2 \%$ of its product to the petroleum/coal sector and $0.5 \%$ to the wood sector. The latter two sectors are selected as the slow-moving variables to identify shocks in the plastic/rubber sector. ${ }^{21}$ Table 3 shows the list of slow-moving variables for each sector.

\footnotetext{
${ }^{20}$ Di Giovanni and Levchenko (2010) regard each entry of the input-output table as representing technological constraints common to all countries and confirm this point by conducting a principal component analysis. Amador and Cabral (2009) reach similar conclusions using a large set of countries including developing countries.

${ }^{21}$ For each TP sectoral output shock, we pick at least two sectors that satisfy this criterion. Since the fabricated metal sector only has one sector that meets the one-percent threshold, we relax the criterion and treat the second-lowest sectors (i.e., wood with $1.1 \%$ shares) as our slow-moving variable. The number of principal components extracted from slow-moving variables is set to two, since by construction it cannot exceed the number of slow-moving variables.
} 
We set the number of extracted factors to three based on the BIC-based information criterion (e.g., Bai and Ng, 2002; Onatski, 2010). ${ }^{22}$ In the FAVAR context, this means that we extract two unobserved factors $(K=2)$ using principal components analysis and append the TP output series as the third "observed" factor. The lag length is set to $P=2$, as suggested by the Schwarz BIC criteria and the Hannan-Quinn IC criteria.

In actual estimation, we also include a recession dummy as an additional exogenous variable, guided by a visual inspection of the time series that shows a large swing during the 2008 global recession. Therefore our estimated model is modified as,

$$
\left[\begin{array}{c}
\tilde{F}_{t} \\
X_{i, t}^{T P}
\end{array}\right]=\Phi(L)\left[\begin{array}{c}
\tilde{F}_{t-1} \\
X_{i, t-1}^{T P}
\end{array}\right]+\boldsymbol{\beta}_{0}^{g r} g r_{t}+\tilde{v}_{t}
$$

where $g r_{t}$ is the recession dummy that takes on the value of one during 2007:12 - 2009:6 and zero otherwise. These dates correspond to the US recession dates determined by the NBER.

For comparison purposes we also estimate a bivariate VAR using the US and TP outputs and a recession dummy. This is to highlight the importance of the additional information contained in the sector-level data of the baseline FAVAR. The VAR model equation is specified as follows,

$$
\left[\begin{array}{c}
X_{i, t}^{U S} \\
X_{i, t}^{T P}
\end{array}\right]=\Phi^{V A R}(L)\left[\begin{array}{l}
X_{i, t-1}^{U S} \\
X_{i, t-1}^{T P}
\end{array}\right]+\boldsymbol{\beta}_{0}^{V A R, g r} g r_{t}+\widetilde{v}_{t}^{V A R}
$$

\footnotetext{
${ }^{22}$ We also experimented with the information criterion proposed by Onatski (2010), which suggests two factors. The scree plot of the eigenvalues is included in Figure A.1 in the appendix. It shows that the eigenvalue clearly levels off after the third principal component.
} 


\section{RESULTS}

\section{(a) Factor Analysis}

Before turning to the FAVAR results, we briefly report the results of the principal component analysis with $K=2$. Figure 2 reports the estimated factor loadings, sorted first by country and then by sector. In the country panel, for the second principal component, we observe a clear contrast between the Americas (US, Canada, Mexico, Peru) and the Asian countries (South Korea, Malaysia, Thailand, Taiwan). This is likely to reflect the economic integration by geographical region. In the sector panel, we note that almost all sectors have large and positive loadings on the first principal component except for a few nondurable goods sectors consisting of food, beverage/tobacco, and petroleum/coal.

We also check how useful the extracted principal components are in explaining the variance of the individual series. Following Boivin, Giannoni, and Mihov (2009), we calculate the degree of fit by dividing the variance of the fitted series by the variance of the original series, i.e. $R_{i}^{2} \equiv \operatorname{var}\left(\hat{\lambda}_{i}^{c} \hat{F}_{t}\right) / \operatorname{var}\left(X_{i, t}^{c}\right)$. Table 4 shows the results. We observe high degrees of fit for the overall outputs ( 0.90 for the US and 0.96 for the TP) and a low degree of fit in the petroleum/coal sector ( 0.05 for the US and 0.06 for the TP).

(b) The US Response to an Overall Trans-Pacific Shock

The top panel of Figure 3 shows the response of the overall US output to a positive one standard deviation shock in the overall TP output. The US output immediately increases following the shock and reaches its peak in four months. The positive response is also statistically significant as shown by the $95 \%$ confidence interval. The strong transmission 
mechanism at the aggregate level is by itself not surprising, given that the TP and the US trade heavily with each other.

The remaining panels of Figure 3 show how US sectors respond to an overall TP shock. The positive shock in the overall TP output generates positive responses in almost all the sectors, but the magnitude differs substantially depending on the sector. The sectors that incur the largest responses are computer/electronics, electrical equipment, machinery, and transportation equipment. These are also the sectors that have the highest trade openness. ${ }^{23}$ This is consistent with the finding in the literature that shows that sectors with a high intensity of trade tend to exhibit strong output co-movements (di Giovanni and Levchenko, 2010).

We note that trade openness does not explain the responses of all the sectors. One clear exception is the mining sector that has high trade openness, but shows a relatively weak response. Another exception is the primary metals sector that has low trade openness, but shows a relatively strong response. It is likely that the nature of goods produced in each sector plays a key role. According to Bems, Johnson, and Yi (2010, 2011), durable goods are known to respond stronger to fluctuations in aggregate production compared with nondurables because trade in durables is highly elastic in response to aggregate production. This explains why the primary metals sector, which is categorized as durable, shows a strong response.

Finally, we check to see whether the results are different when using a FAVAR as opposed to a VAR. We note that the overall output response generated through the FAVAR exceeds that of the VAR by almost twofold. This implies that the additional sectoral variables in

\footnotetext{
${ }^{23}$ see Table A.3 in the online appendix for the definition of trade openness.
} 
the FAVAR contain useful information not captured by the traditional VAR. In addition, the responses of individual sectors are also quite different. In the computer/electronics and transportation equipment sectors where vertical production linkages appear to be strong, the responses using the FAVAR exceed the responses using the VAR in the months immediately following the shock. Combined with the empirical studies that find a positive association between vertical production linkages and the business cycle, the results from the FAVAR make more sense than the VAR results.

(c) The Response of the US to Sectoral Trans-Pacific Shocks

Figure 4 shows how the overall output in the US responds to one standard deviation shocks in the individual TP sectors. We find that the TP shocks in eleven of the sixteen sectors yield significant and positive responses in the overall US output. Further examination reveals that TP shocks in plastic/rubber, primary metals, machinery, computer/electronics, and transportation equipment yield the largest responses in the overall US output, implying that these five sectors have a particular importance for the US economy.

Because output variations differ by sector, the sizes of the sectoral shocks are also different, making the responses of the US output not directly comparable. Therefore, in addition to impulse responses, we construct our own normalized measures by dividing the sum of US responses in the first six periods by that of the sum of the TP responses. This "responsiveness" measure is defined as follows:

$$
\varepsilon_{T P, i}^{U S, I P}=\frac{\sum_{t=1}^{6} I R F_{I P, t}^{U S}}{\sum_{t=1}^{6} I R F_{i, t}^{T P}}
$$


where $I R F_{i, t}$ is the impulse response of sector $i$ in either US or TP. We also prepared another measure that estimates how long the response lasts, following Mackowiak, Moench, and Wiederholt (2009). This "speed of response" is constructed as,

$$
S_{T P, j}^{U S, I P}=\frac{\frac{1}{6} \sum_{t=1}^{6}\left|I R F_{I P, t}^{U S}\right|}{\frac{1}{6} \sum_{t=7}^{12}\left|I R F_{I P, t}^{U S}\right|} .
$$

A higher speed of response means that the shock has a quick, but only temporary effect on the US economy. Table 5 reports these two measures.

We find that the fabricated metals, petroleum/coal, and plastic/rubber sectors show relatively high responsiveness compared to the other sectors, while food and beverage/tobacco sectors have a low responsiveness. We note that products in fabricated metals, petroleum/coal, and plastic/rubber sectors are generally used as intermediate goods. As noted by Bridgman (2012) and Luong (2011), intermediate inputs tend to have a low substitution elasticity, which means that the US cannot easily replace goods produced in foreign countries with goods produced domestically. Thus sectors that involve more intermediate goods may have a larger effect on the US economy.

To examine whether our results align with the argument related to substitution elasticity, we compare the impulse responses with the degree of intermediate use for each sector. ${ }^{24}$ On the one hand, sectors that have a high degree of intermediate use, such as primary metals, generally have a larger impact on the US economy (with the exception of mining and wood). On the other hand, sectors such as food and beverage/tobacco, which are known to have high substitution

\footnotetext{
${ }^{24}$ For this experiment, we calculate the degree of intermediate use for each sector as the ratio of intermediate use over total output. These ratios are shown in Table A.3 in the online appendix.
} 
elasticities according to the existing studies, generally show relatively low responsiveness. ${ }^{25}$ Thus the argument that substitution elasticity and responsiveness are inversely related seems to hold reasonably well.

We further note in Table 5 that sectors that cause a large impulse response in the US are not necessarily associated with a large responsiveness. For example, TP computer/electronics only has a responsiveness of 0.51 , ranked twelfth overall. Thus the reason for the large response of overall US output from the computer/electronics shock must be caused by the large size of shock (15.84\%, ranked second overall) rather than the responsiveness to the shock. In contrast, TP plastic/rubber has a responsiveness of 0.92 , ranked fourth overall. This explains why the US economy responds strongly to the plastic/rubber shock, despite its moderate size of shock $(8.10 \%$, ranked seventh overall).

The last column of Table 5 reports the speed of response. Shocks in computer/electronics and transportation equipment sectors are found to have relatively longer-lasting effects $(0.85$ 1.29) whereas for the machinery sector the effect seems to be rather short-lived (3.12). This contrasting result is rather surprising given that these three sectors are often grouped together as "machinery-related" sectors in empirical work.

(d) The Response of the US Sectors to Same-Sector Trans-Pacific Shocks

In this section, we study the response of US sectors to the same-sector TP shock. If the sectoral response is larger than the overall output response, it indicates that vertical production

\footnotetext{
${ }^{25}$ For more on the individual estimates of substitution elasticity, see Broda and Weinstein (2006), Chen and Novy (2011), Imbs and Mejean (2009), and Luong (2011).
} 
linkage may play an active role in transmitting shocks. For this experiment, we select the five TP sectors (plastic/rubber, primary metals, machinery, computer/electronics, and transportation equipment) that yield the largest responses in the overall output. Figure 5 shows the effects of the TP sectoral outputs on overall US output and US same-sector output. ${ }^{26}$

We observe that in three of the five sectors (computer/electronics, primary metals and transportation equipment), the sectoral outputs clearly show larger responses relative to the overall output response following the shock, suggesting that a vertical production linkage is of high relevance in these sectors. In contrast, the responses of the US plastics/rubber and machinery sectors are similar to the response of the overall US output. This indicates that across-sectoral transmission is also in play for these sectors, a point noted by Bems, Johnson, and Yi (2010). This makes sense since both sectors sell much of their product to other sectors rather than to themselves, as shown in the US input-output table.

We further note that the sectoral responses for primary metals and transportation equipment slightly "lead" the overall responses. This is consistent with the "cascade effect" hypothesis discussed in Acemoglu, Carvalho, Ozdaglar, and Tahbaz-Salehi (2012) in which a small shock in a given TP sector can cascade through a sequence of interconnected US sectors to generate a large fluctuation in aggregate US output although with a delay.

\section{ROBUSTNESS CHECKS}

(a) The Effect of Omitted Variables

\footnotetext{
${ }^{26}$ Figure A.2 in the appendix shows the results for all sixteen sectors.
} 
In the baseline FAVAR specification, the only variable that we included other than the output series was the recession dummy, but there may be other variables that could affect business cycle transmission in this region. We consider two variables: the global oil price and the overall Chinese industrial production. The price of oil is a common control variable in the literature to account for exogenous oil supply shocks. ${ }^{27}$ China is a major trading partner for all the sample countries and plays an integral part in the vertical production linkage within the AsiaPacific region. ${ }^{28}$ As before, both variables are transformed into 12-month log differences to induce stationarity.

To account for the effect of these two variables, we augment our FAVAR model in Equation (1) as follows:

$$
\left[\begin{array}{c}
\tilde{F}_{t} \\
X_{I P, t}^{C h n} \\
X_{j, t}^{T P}
\end{array}\right]=\Phi^{a l t}(L)\left[\begin{array}{c}
\widetilde{F}_{t-1} \\
X_{I P, t-1}^{C h n} \\
X_{j, t-1}^{T P}
\end{array}\right]+\boldsymbol{\beta}_{0}^{o i l} \text { oil }_{t}+\boldsymbol{\beta}_{1}^{o i l} \text { oil }_{t-1}+\boldsymbol{\beta}_{2}^{o i l} \text { oil }_{t-2}+\boldsymbol{\beta}_{0}^{g r} g r_{t}+\widetilde{v}_{t}
$$

where $X_{I P, t}^{C h n}$ is the industrial production for China and $o i l_{t}$ is the price of oil. ${ }^{29}$ We treat $X_{I P, t}^{C h n}$ as an endogenous variable to allow dynamic feedbacks in the model and order the variable before the TP variable to preserve the recursive order of the variables as in the baseline model.

\footnotetext{
${ }^{27}$ Dellas (1986) regards oil shocks as one of the reasons why trade is insignificant in explaining international economic fluctuations. Lee and $\mathrm{Ni}$ (2002) find that oil price shocks can induce downturns in different sectors of an economy.

${ }^{28}$ For example, Dietzenbacher, Los, Gaaitzen, and Timmer (2015) show how the global automotive production is transformed when China is added to the production chain. Similarly, Amador and Cabral (2009) and Johnson and Noguera (2012) study the role of China in the regional supply chain. Li and Whalley (2014) demonstrate the important role that China plays in the regional production through simulating a hypothetical scenario of China joining the TPP.

${ }^{29}$ The time series for oil prices and Chinese industrial production are obtained from the FRED and IMF websites respectively. The oil price variable is the Crude Oil Price: West Texas Intermediate (WTI) - Cushing, Oklahoma (DCOILWTICO). Chinese industrial production is obtained in the form of the annual growth rate. We adjust for the Chinese New Year effect that occurs every year around January and February by taking the local average excluding the outlier month.
} 
The left column of Figure 6 shows how the overall US output responds to a shock in the overall TP output when we add into the equation the oil price and the Chinese industrial production each separately and then jointly. The responses of the expanded model mostly remain within the $95 \%$ confidence interval of the baseline response. We notice some minor differences: the peak response becomes slightly lower and the timing of the peak is slightly earlier than in the baseline specification. We conclude that oil prices and the Chinese output do not have a large impact on our results.

In the original specification, US mining initially responded slightly negatively to a $\mathrm{TP}$ shock. This was puzzling given that mining has a very high degree of intermediate use and also a high degree of trade openness. When we add Chinese industrial production, the immediate response of US mining becomes closer to zero in the beginning, but the quantitative effect remains minor. The effect is not altered when we add just the oil price, just Chinese industrial production, or both oil price and Chinese industrial production. ${ }^{30}$

(b) The Number of Factors, Lags, and the Selection of the Slow-Moving Variables

We also check whether our baseline results are sensitive to the number of factors or lags. For the principal component estimators to consistently cover the factor space, the number of factors has to be equal to or greater than its "true" number (Onatski, 2010). It is therefore customary in the FAVAR literature to conduct a robustness check by experimenting with a larger number of extracted principal components than the baseline specification. We set the number of

\footnotetext{
${ }^{30} \mathrm{We}$ have also experimented with the EU industrial production and gold prices, but the results are similar to those found here.
} 
principal components, $K$ to eight. ${ }^{31} \mathrm{We}$ also experimented with a larger number of lags by setting the number of lags, $P$, equal to thirteen. ${ }^{32}$ Figure A.3 in the appendix shows the impulse responses of the overall US output to a shock in the overall TP output under the alternative specifications. We present the results for the US sectors that are relatively large in terms of employment in Figure A.4 in the appendix. In all cases, the impulse responses in the alternative specifications remain in relatively close proximity to the baseline response, largely within the baseline confidence intervals throughout the time horizon. The responses with a larger number of factors and lags display oscillations and/or noisy edges, indicating that there may be overfitting.

We also experimented with alternative identification strategies. Recall that the slowmoving variables were selected based on the one-percent spending share in the input-output table. This approach could lead to selecting too many slow-moving variables for sectors that sell a large portion of their products to themselves and little to other sectors (e.g. food and transportation equipment sectors). Thus we narrow the criterion by selecting sectors with the smallest shares in the production process and reduce the number of slow-moving variables to two. The alternative set of slow-moving variables is shown in bold letters in Table 3 . Figure A.5 in the appendix shows how the overall US output responds to a positive one standard deviation shock in selected sectoral outputs in the TP region. ${ }^{33}$ We observe that for the majority of the sectors the impulse responses remain similar to those in the baseline and stay within the $95 \%$

\footnotetext{
${ }^{31}$ This is based on Bai and Ng's (2002) suggested rule to cap the maximum number of factors at $8=\left(\operatorname{int}\left[\frac{\min \{N, T\}}{100}\right]^{\frac{1}{4}}\right)$.

32 This choice is conventional in FAVAR models that use monthly growth rates (Bernanke, Boivin, and Eliasz, 2005 and Boivin, Giannoni, and Mihov, 2009). Since our output series are transformed into annual growth rates, this number is meant to be suggestive and is used as the upper bound.

${ }^{33}$ We skip the other four sectors because their original number of slow-moving variables was two and the responses are identical to those in Figure 6.
} 
confidence interval of the baseline response. For the electrical equipment, transportation equipment, and furniture sectors, the responses are larger than the baseline response. In qualitative terms, our results remain largely unaltered from the baseline results.

(c) Alternative Aggregation Method in Constructing Trans-Pacific Variables

We also check whether the baseline results are sensitive to an alternative method of constructing our TP variables. In particular, we construct the relevant TP variables using the method of principal components as described in online Appendix B. ${ }^{34}$ One key feature of this method is that we no longer impose the assumption that GDP shares of all countries are constant. In addition, the individual TP countries receive equal weights in this alternative aggregation process. Figures A.6 and A.7 in the appendix repeat the same exercises as in Figures 3 and 4 using the newly prepared series. The impulse responses remain similar to those in the baseline cases. The only exception is the response of the overall US output to a TP machinery shock, where the confidence interval has widened and the positive response is no longer significant. Therefore, we conclude that adopting a fixed-weight method in constructing TP variables is not responsible for yielding our main results.

(d) The Role of Canada

Finally, we check whether our results are largely driven by the presence of Canada in our definition of Trans-Pacific region. Canada is by far the economy most integrated with the US among the eight Trans-Pacific countries that we consider. Earlier, in Figure 2, we have seen that

\footnotetext{
${ }^{34}$ Table A.4 in the online appendix shows a summary statistics of the newly prepared series and the correlation coefficient with the TP variables used in baseline analysis.
} 
the US and Canada share common principal components, presumably reflecting the extent of regional integration within the Americas. Therefore it would be of interest to see whether our main results would still hold if we leave out Canada from our definition of the Trans-Pacific region. Figure 7 shows the impulse response of the overall US output to a shock on both the TP output excluding Canada (left panel) and the Canadian output by itself (right panel). For the former case, the response of US output is slightly smaller compared to the baseline case with Canada, but stays well within the confidence interval of the baseline response. A Canadian output shock draws a positive response of the US output, but the effect is only significant in the earlier months. Figures A.8 - A.10 in the appendix repeat the same exercises as in Figures 3-5 in the main text, but treating the Trans-Pacific region and Canada separately. While the US output responses to the Canadian output shocks look generally different from the case with TP output shocks, the US responses to the TP output shock excluding Canada remain close to our baseline results, both in shape and magnitude. We thus conclude that the exclusion of Canada from our definition of Trans-Pacific region does not significantly alter the main findings of the paper.

\section{Discussion and Conclusions}

This paper studies how the US economy in the aggregate and the sector levels react to shocks from the Trans-Pacific region. Using a large panel of time series data that include nine countries and sixteen major sectors, we estimate a factor-augmented vector autoregression (FAVAR) model to simulate the effect of shocks in the Trans-Pacific region on the US economy. We show that a positive shock in the overall output of the Trans-Pacific region has varying 
effects on different sectoral outputs in the US. In particular, computer/electronics, electrical equipment, machinery, and transportation equipment in the US are the sectors most affected by the Trans-Pacific shocks. Our results are largely consistent with the findings in the literature that sectors that are more open to trade and sectors that produce durable goods tend to display stronger output co-movements between countries.

Surprisingly, we find that several sector-level shocks in the Trans-Pacific region not only generate large same-sector responses in the US, but also generate a large response in the overall US output. Specifically, the shocks from five sectors (plastics/rubber, primary metals, machinery, computer/electronics, and transportation equipment) have a significant impact on the overall US output.

Among the five sectors, computer/electronics, primary metals, and transportation equipment generate large and positive same-sector responses compared with the overall response, suggesting that vertical production linkages are likely to contribute to the large overall response. Many studies document strong vertical production linkages in the computer/electronics and transportation equipment sectors within the region. For example, Amador and Cabral (2009) find that in East Asia vertical specialization is prevalent in high-tech industries. Kimura (2006) reports that the exports of parts and components in the computer/electronics sector in East Asia have grown at a rapid pace between 1990-2003. ${ }^{35}$ McCalman and Spearot (2013) note that after

\footnotetext{
${ }^{35}$ See also Authkorala and Yamashita (2006), Kimura, Takahashi, and Hayakawa (2007), and Kumakura (2006).
} 
NAFTA was enacted in 1993, the US auto industry relocated much of its light truck production to Mexico, causing a rapid growth in the auto trade during the past decade. ${ }^{36}$

The large impact on the US economy from relatively small Trans-Pacific sectors, such as plastic/rubber and primary metals, seems surprising. We note that this result is in contrast to the generally held view that the effect of a sectoral shock tends to quickly average out when there are multiple sectors (e.g., Lucas, 1977). There are several possible reasons. First, these products are mostly used as intermediate goods, and there is a low elasticity of substitution between domestic and foreign-produced goods. Second, the metals sector in general has a relatively high degree of vertical specialization (Midourot and Ragoussis, 2009).

Our results also attest to the importance of using sectoral data in studying business cycle transmission in the Trans-Pacific region. The impulse responses from the FAVAR significantly differ from those of bivariate VARs, suggesting that using aggregate industrial production alone by itself may obscure the transmission mechanisms at the sectoral level.

Our findings regarding the heterogeneity of sectors are consistent with the current line of theoretical research that focuses on the different nature of sectors in generating strong amplification mechanisms for shocks. To name a few, Burstein, Kurz, and Tesar (2008) assume that goods that involve vertically integrated production-sharing have a lower elasticity of substitution than horizontally differentiated goods. Bergin, Feenstra, and Hansen (2011) assume that offshoring sectors have a varying unit labor cost that triggers adjustment in the offshoring margin. Bridgman (2012) and Huang and Liu (2007) build multi-stage line of production models

\footnotetext{
${ }^{36}$ See also Gereffi, Sturgeon, and Van Biesebroeck (2008), Van Biesebroeck and Zhang (2012), Dietzenbacher, Los, Gaaitzen, and Timmer (2015), and Yi (2010).
} 
in which sectors in each production stage have different factor intensities. ${ }^{37}$ We think that future research on the Trans-Pacific region should focus more on sectoral analysis as these and other studies suggest.

Finally, our results shed light on the future business cycle transmission between the Trans-Pacific and the US when the Trans-Pacific Partnership Agreement becomes effective. On one hand, the elimination of trade barriers is likely to increase the interdependency of member countries through the trade channel. But on the other hand, harmonizing rules and regulations for cross-border investment may result in increased local sales that potentially replace international trade. During the post-NAFTA era of 1993-2003, we saw an almost twofold increase in the trade of motor vehicles among the NAFTA countries (Hufbauer and Schott, 2005), an observation which supports the idea that trade increases with regional trade agreement. With regard to the future of regional interdependency, one important factor is whether Japan will be granted full access to the US light trucks, passenger cars, and auto parts market in the near future. This would significantly speed up the economic integration of US into the Trans-Pacific region and strengthen the interdependency of all the current and potential TPP member countries.

\section{BIBLIOGRAPHY}

Acemoglu, Daren, Vasco M. Carvalho, Asuman Ozdaglar, and Alireza Tahbaz-Salehi. (2012). "The Network Origins of Aggregate Fluctuations," Econometrica, 80(5), 1977-2016.

Amador, João, and Sónia Cabral. (2009). "Vertical Specialization across the World: A Relative Measure," The North American Journal of Economics and Finance, 20(3), 267-280.

\footnotetext{
${ }^{37}$ For other attempts, see Bridgman (2008), Engel and Wang (2011), Tesar (2008), and Yi (2010).
} 
Ando, Mitsuyo. (2006). "Fragmentation and Vertical Intra-Industry Trade in East Asia," The North American Journal of Economics and Finance, 17(3), 257-281.

Andrews, Donald W. K. and Eric Zivot. (1992). "Further Evidence on the Great Crash, the Oil Price Shock, and the Unit-root Hypothesis," Journal of Business and Economic Statistics, 10(3), 251-270.

Athukorala, Prema-chandra, and Nobuaki Yamashita. (2006). "Production Fragmentation and Trade Integration: East Asia in a Global Context," The North American Journal of Economics and Finance, 17(3), 233-256.

Bagliano, Fabio C., and Claudio Morana. (2009). "International Macroeconomic Dynamics: A Factor Vector Autoregressive Approach,” Economic Modelling, 26(2), 432-444.

Bai, Jushan and Serena Ng. (2002). "Determining the Number of Factors in Approximate Factor Models," Econometrica, 70(1), 191-221.

Barfield, Claude. (2009). "Politics of Trade in the USA and in the Obama Administration: Implications for Asian Regionalism," Asian Economic Policy Review, 4(2), 227-243.

Baxter, Marianne and Michael A. Kouparitsas. (2005). "Determinants of Business Cycle Comovement: A Robust Analysis,” Journal of Monetary Economics, 52, 113-157.

Bems, Rudolf, Robert C. Johnson, and Kei-Mu Yi. (2010). "Demand Spillovers and the Collapse of Trade in the Global Recession.” IMF Economic Review, 58, 2, 295-326.

Bems, Rudolfs, Robert C. Johnson, and Kei-Mu Yi. (2011). "Vertical Linkages and the Collapse of Global Trade," The American Economic Review, 2011, 308-312.

Bergin, Paul R., Robert C. Feenstra, and Gordon H. Hanson. (2011). "Volatility due to Offshoring: Theory and Evidence,” Journal of International Economics, 85(2), 163-173.

Bernanke, Ben S., Jean M. Boivin, and Piotr Eliasz. (2005). "Measuring the Effects of Monetary Policy: A Factor-Augmented Vector Autoregressive (FAVAR) approach," The Quarterly Journal of Economics, 120(1), 387-422.

Boivin, Jean, and Marc P. Giannoni. (2010). "Global Forces and Monetary Policy Effectiveness," International Dimensions of Monetary Policy, edited by Jordi Gali and Mark J. Gertler, chapter 8, 429-488, University of Chicago Press.

Boivin, Jean M., Marc P. Giannoni, and Ilian Mihov. (2009). "Sticky Prices and Monetary Policy: Evidence from Disaggregated Data," American Economic Review, 99(1), 350-384. 
Bridgman, Benjamin. (2008). "Energy Prices and the Expansion of World Trade," Review of Economic Dynamics,11(4), 904-916.

Bridgman, Benjamin. (2012). "The Rise of Vertical Specialization Trade,” Journal of International Economics, 86(1), 133-140.

Broda, Christian, and David E. Weinstein. (2006). "Globalization and the Gains From Variety," The Quarterly Journal of Economics, 121(2), 541-585.

Burstein, Ariel, Christopher Kurz, and Linda Tesar. (2008). "Trade, Production Sharing, and the International Transmission of Business Cycles," Journal of Monetary Economics, 55, 775-795.

Calderón, César, Alberto Chong, and Ernesto Stein. (2007). "Trade Intensity and Business Cycle Synchronization: Are Developing Countries Any Different?" Journal of International Economics, 71, 2-21.

Canova, Fabio, Matteo Ciccarelli, and Eva Ortega. (2007). "Similarities and Convergence in G-7 Cycles," Journal of Monetary Economics, 54(3), 850-878.

Chen, Hogan, Matthew Kondratowicz, and Kei-Mu Yi. (2005). "Vertical Specialization and Three Facts about US International Trade," The North American Journal of Economics and Finance, 16(1), 35-59.

Chen, Natalie, and Dennis Novy. (2011). "Gravity, Trade Integration, and Heterogeneity across Industries,” Journal of International Economics, 85(2), 206-221.

Crosby, Mark. (2003). "Business Cycle Correlations in Asia-Pacific,” Economic Letters, 80, 35-44.

Daudin, Guillaume, Christine Rifflart, and Danielle Schweisguth. (2011). "Who Produces for Whom in the World Economy?” Canadian Journal of Economics, 44(4), 1403-1437.

Dellas, Harris. (1986). “A Real Model of the World Business Cycle,” Journal of International Money and Finance, 5, 381-394.

Dietzenbacher, Erik, Bart Los, Robert Stehrer, Gaaitzen J. Vries, and Marcel P. Timmer. (2015). "An Illustrated User Guide to the World Input-Output Database: The Case of Global Automotive Production," Review of International Economics, 23(3), 575-605.

di Giovanni, Julian and Andrei A. Levchenko. (2010). "Putting the Parts Together: Trade, Vertical Linkages, and Business Cycle Comovement," American Economic Journal: Macroeconomics, 2(2), 95-124.

Engel, Charles and Jian Wang. (2011). "International trade in durable goods: Understanding volatility, cyclicality, and elasticities.” Journal of International Economics, 83, 37-52. 
Frankel, Jeffrey A. and Andrew K. Rose. (1998). "The Endogeneity of the Optimum Currency Area Criteria," The Economic Journal, 108, 449, 1009-1025.

Gereffi, Gary, Timothy Sturgeon, and Johannes Van Biesebroeck. (2008). "Value Chains, Networks and Clusters: Reframing the Global Automotive Industry," Journal of Economic Geography, 8(3), 297-321.

Gerlach, H.M. Stefan. (1988). "World Business Cycles Under Fixed and Flexible Exchange Rates," Journal of Money, Credit and Banking, 20(4), 621-632.

Helg, Rodolfo, Paolo Manasse, Tommaso Monacelli, and Riccardo Rovelli. (1995). "How much (a)symmetry in Europe? Evidence from industrial sectors," European Economic Review, 39(5), 1017-1041.

Helpman, Elhanan. (2006). "Trade, FDI, and the Organization of Firms," Journal of Economic Literature, 44(3), 589-630.

Huang, Kevin X. D. and Zheng Liu. (2007). "Business Cycles with Staggered Prices and International Trade in Intermediate Inputs," Journal of Monetary Economics, 54, 1271-1289.

Hufbauer, Gary C. and Jeffrey J. Schott. (2005). 'NAFTA Revisited: Achievements and Challenges,' Peterson Institute.

Hummels, David. (2007). "Transportation Costs and International Trade in the Second Era of Globalization," The Journal of Economic Perspectives, 21(3), 131-54.

Hummels, David, Jun Ishii, and Kei-Mu Yi. (2001). "The Nature and Growth of Vertical Specialization in World Trade," Journal of International Economics, 54(1), 75-96.

Imbs, Jean. (2004). "Trade, Finance, Specialization, and Synchronization," Review of Economics and Statistics, 86(3), 723-734.

Imbs, Jean M., and Isabelle Méjean. (2009). "Elasticity Optimism," IMF Working Papers, 2009, $1-45$.

Inklaar, Robert, Richard Jong-A-Pin, and Jakob de Haan. (2008). "Trade and Business Cycle Synchronization in OECD Countries - A Re-examination," European Economic Review, 52, 646-666.

Johnson, Robert C. (2014). "Five Facts about Value-Added Exports and Implications for Macroeconomics and Trade Research," The Journal of Economic Perspectives, 28(2), 119-142. 
Johnson, Robert C. and Guillermo Noguera. (2012). "Accounting for Intermediates: Production Sharing and Trade in Value Added," Journal of International Economics, 86(2), 224-236.

Kilian, Lutz. (1998). "Small-sample Confidence Intervals for Impulse Response Functions," Review of Economics and Statistics, 80(2), 218-230.

Kimura, Fukunari. (2006). "International Production and Distribution Networks in East Asia: Eighteen Facts, Mechanics, and Policy Implications," Asian Economic Policy Review, 1, 326-344.

Kimura, Fukunari, Yuya Takahashi, and Kazunobu Hayakawa. (2007). "Fragmentation and Parts and Components Trade: Comparison between East Asia and Europe," The North American Journal of Economics and Finance, 18(1), 23-40.

Kumakura, Masanaga. (2006). "Trade and Business Cycle Co-Movements in Asia-Pacific," Journal of Asian Economics, 17(4), 622-645.

Lee, Kiseok and Shawn Ni. (2002). "On the Dynamic Effects of Oil Price Shocks: A Study Using Industry Level Data.” Journal of Monetary Economics, 49, 823-852.

Li, Chunding and John Whalley. (2014). "China and the Trans-Pacific Partnership: A Numerical Simulation Assessment of the Effects Involved," The World Economy, 37(2), 169-192.

Liu, Philip, Haroon Mumtaz, and Angeliki Theophilopoulou. (2014). "The Transmission of International Shocks to the UK. Estimates Based on a Time-Varying Factor Augmented VAR," Journal of International Money and Finance, 46, 1-15.

Lucas, Robert E. (1977). "Understanding Business Cycles," Carnegie-Rochester Conference Series on Public Policy, 5, 7-29.

Luong, Tuan Anh. (2011). "The Impact of Input and Output Tariffs on Firms' Productivity: Theory and Evidence," Review of International Economics, 19(5), 821-835.

Mackowiak, Bartosz, Emanuel Moench, and Mirko Wiederholt. (2009). "Sectoral Price Data and Models of Price Setting," Journal of Monetary Economics, 56, S78-S99.

McCalman, Phillip, and Alan Spearot. (2013). "Why Trucks Jump: Offshoring and Product Characteristics," Journal of International Economics, 91(1), 82-95.

Mercurio, Bryan. (2014). “The Trans-Pacific Partnership: Suddenly a 'Game Changer'," The World Economy, 37(11), 1558-1574.

Miroudot, Sébastien and Alexandros Ragoussis. (2009). "Vertical Trade, Trade Costs and FDI," OECD Trade Policy Papers, 89, OECD Publishing. 
Mumtaz, Haroon and Paolo Surico. (2009). "The Transmission of International Shocks: A Factor-Augmented VAR Approach," Journal of Money, Credit and Banking, Supplement to 41(1).

Ng, Eric C.Y. (2010). "Production Fragmentation and Business-Cycle Comovement," Journal of International Economics, 82(1), 1-14.

Onatski, Alexei. (2010). "Determining the Number of Factors from Empirical Distribution of Eigenvalues," Review of Economics and Statistics, 92(4), 1004-1016.

Petri, A. Peter and Michael G. Plummer. (2012). "The Trans-Pacific Partnership and AsiaPacific Integration: Policy Implications," Peterson Institute for International Economics Policy Brief, 12-16.

Rana, Pradumna B. (2007). "Economic Integration and Synchronization of Business Cycles in East Asia," Journal of Asian Economics, 18, 711-725.

Shin, Kwanho and Yunjong Wang. (2003). "Trade Integration and Business Cycle Synchronization in East Asia," Asian Economic Papers, 2(3), 1-20.

Tesar, Linda L. (2008). "Production Sharing and Business Cycle Synchronization in the Accession Countries,” NBER International Seminar on Macroeconomics, 2006.

Van Biesebroeck, Johannes, and Lijun Zhang. (2014). "Interdependent Product Cycles for Globally Sourced Intermediates," Journal of International Economics, 94(1), 143-156.

Vasishtha, Garima, and Philipp Maier. (2013). "The Impact of the Global Business Cycle on Small Open Economies: A FAVAR Approach for Canada," The North American Journal of Economics and Finance, 24, 191-207.

Williams, Brock R. (2013). "Trans-Pacific Partnership (TPP) Countries: Comparative Trade and Economic Analysis," Congressional Research Service, Washington, DC.

Yi, Kei-Mu. (2010). "Can Multistage Production Explain the Home Bias in Trade?" The American Economic Review, 100(1), 364-393. 
Table 1: Summary Statistics for the Trans-Pacific Region and the US

\begin{tabular}{|c|c|c|c|c|}
\hline & $\begin{array}{l}\text { Population } \\
\text { in millions }\end{array}$ & $\begin{array}{l}\text { GDP in } \\
\text { billions } \$\end{array}$ & $\begin{array}{l}\text { Trade- } \\
\text { to-GDP } \\
\text { ratio }\end{array}$ & Major Industrial Sectors \\
\hline Year & 2014 & 2013 & 2013 & $2001-2012$ \\
\hline Japan & $\begin{array}{c}127.1 \\
(15.9 \%)\end{array}$ & $\begin{array}{l}4,919.59 \\
(17.9 \%)\end{array}$ & $31.5 \%$ & $\begin{array}{l}\text { Transportation equipment }(2.5 \%) \text {, } \\
\text { computer/electronics }(2.4 \%) \text {, machinery } \\
(2.1 \%)\end{array}$ \\
\hline Canada & $\begin{array}{c}34.8 \\
(4.3 \%)\end{array}$ & $\begin{array}{c}1,838.96 \\
(6.7 \%)\end{array}$ & $51.1 \%$ & $\begin{array}{l}\text { Mining }(8.3 \%) \text {, transportation equipment } \\
(1.8 \%) \text {, food }(1.4 \%) \text {, primary metals } \\
(1.0 \%)\end{array}$ \\
\hline South Korea & $\begin{array}{c}49.0 \\
(6.1 \%)\end{array}$ & $\begin{array}{c}1,305.61 \\
(4.8 \%)\end{array}$ & $82.4 \%$ & $\begin{array}{l}\text { Computer/electronics }(4.5 \%), \\
\text { transportation equipment }(3.7 \%)\end{array}$ \\
\hline Mexico & $\begin{array}{c}120.3 \\
(15.0 \%)\end{array}$ & $\begin{array}{c}1,261.86 \\
(4.6 \%)\end{array}$ & $61.2 \%$ & $\begin{array}{l}\text { Mining }(9.3 \%) \text {, food (3.9\%), chemical } \\
(2.3 \%) \text {, transportation equipment }(2.2 \%)\end{array}$ \\
\hline Taiwan & $\begin{array}{c}23.4 \\
(2.9 \%)\end{array}$ & $\begin{array}{l}511.28 \\
(1.9 \%)\end{array}$ & n.a. & $\begin{array}{l}\text { Computer/electronics }(16.7 \%) \text {, chemical } \\
(6.9 \%) \text {, primary metal }(4.8 \%)\end{array}$ \\
\hline Thailand & $\begin{array}{c}67.7 \\
(8.4 \%)\end{array}$ & $\begin{array}{l}420.17 \\
(1.5 \%)\end{array}$ & $123.8 \%$ & $\begin{array}{l}\text { Wood }(3.5 \%) \text {, paper }(3.4 \%) \text {, chemical } \\
(3.0 \%) \text {, nonmetallic mineral }(2.7 \%)\end{array}$ \\
\hline Malaysia & $\begin{array}{c}30.1 \\
(3.8 \%)\end{array}$ & $\begin{array}{l}323.34 \\
(1.2 \%)\end{array}$ & $138.7 \%$ & $\begin{array}{l}\text { Mining }(10.8 \%) \text {, computer/ electronics } \\
(6.1 \%) \text {, petroleum/coal }(3.1 \%)\end{array}$ \\
\hline Peru & $\begin{array}{c}30.1 \\
(3.8 \%)\end{array}$ & $\begin{array}{l}201.88 \\
(0.7 \%)\end{array}$ & $42.4 \%$ & $\begin{array}{l}\text { Mining }(5.9 \%) \text {, food }(3.9 \%) \text {, chemical } \\
(1.5 \%) \text {, nonmetallic mineral }(1.4 \%)\end{array}$ \\
\hline TP Total & $\begin{array}{c}482.5 \\
(60.2 \%)\end{array}$ & $\begin{array}{c}10,782.68 \\
(39.3 \%)\end{array}$ & - & $\begin{array}{l}\text { Mining }(2.8 \%), \text { computer/ electronics } \\
(2.8 \%) \text {, transportation }(2.4 \%) \text {, chemical } \\
(2.0 \%)\end{array}$ \\
\hline US & $\begin{array}{c}318.9 \\
(39.8 \%)\end{array}$ & $\begin{array}{c}16,663.15 \\
(60.7 \%)\end{array}$ & $23.3 \%$ & $\begin{array}{l}\text { Chemical }(2.1 \%) \text {, mining }(1.8 \%) \text {, } \\
\text { transportation equipment }(1.5 \%) \text {, } \\
\text { computer/electronics }(1.3 \%)\end{array}$ \\
\hline $\mathrm{TP}+\mathrm{US}$ & $\begin{array}{c}801.40 \\
(100.0 \%) \\
\end{array}$ & $\begin{array}{r}27,445.83 \\
(100.0 \%) \\
\end{array}$ & - & \\
\hline
\end{tabular}

Note: The population is in millions. The GDP is in billions of current US dollars. The Trans-Pacific (TP) region, as used in this study, covers a total of eight countries (Canada, Japan, South Korea, Mexico, Malaysia, Peru, Thailand, and Taiwan). Population and GDP shares are calculated as a percentage of the total in the Trans-Pacific region. The data for the population are obtained from the CIA Handbook. The GDP figures are obtained from the World Economic Outlook Database. The trade-to-GDP ratios are obtained from the World Bank, World Development Indicators. The data used to calculate the shares are obtained from individual government agencies. 
Table 2: Summary Statistics for All Industries in the Trans-Pacific Region and the US, 2001-2012

\begin{tabular}{|c|c|c|c|c|c|c|}
\hline & & $\mathrm{TP}$ & & US & & TP and US \\
\hline & $\begin{array}{l}\text { Abbrev- } \\
\text { iation }\end{array}$ & $\begin{array}{c}\text { Mean } \\
\text { growth } \\
\text { rate }\end{array}$ & St. dev & $\begin{array}{l}\text { Mean } \\
\text { growth } \\
\text { rate }\end{array}$ & St. dev & $\begin{array}{l}\text { Correlation } \\
\text { Coefficient }\end{array}$ \\
\hline Aggregate Industrial Production & $I P$ & 1.01 & 7.66 & 0.52 & 4.93 & 0.84 \\
\hline Mining (21) & Min & 0.73 & 3.47 & 1.02 & 4.45 & 0.33 \\
\hline Food (311) & Food & 0.53 & 1.74 & 0.83 & 1.68 & 0.12 \\
\hline Beverage/tobacco (312) & $B e v$ & 0.64 & 3.78 & -0.76 & 5.44 & 0.16 \\
\hline Wood (321) & Wood & -3.44 & 8.50 & -2.22 & 10.48 & 0.72 \\
\hline Paper (322) & Paper & -0.24 & 5.29 & -1.85 & 4.75 & 0.86 \\
\hline Petroleum/coal (324) & Petro & 0.35 & 3.40 & 0.97 & 4.34 & 0.09 \\
\hline Chemical (325) & Chem & 1.39 & 4.78 & 0.48 & 5.68 & 0.68 \\
\hline Plastic/rubber (326) & Plas & -0.27 & 8.10 & -1.07 & 7.32 & 0.82 \\
\hline Nonmetallic minerals (327) & Nmet & 0.27 & 7.17 & -2.16 & 9.45 & 0.75 \\
\hline Primary metals (331) & Pmet & 0.34 & 11.99 & -0.18 & 13.42 & 0.90 \\
\hline Fabricated metals (332) & Fmet & -0.85 & 6.15 & -0.23 & 9.59 & 0.86 \\
\hline Machinery (333) & Mach & 0.28 & 17.09 & 0.38 & 11.11 & 0.87 \\
\hline Computer/electronics (334) & Comp & 3.91 & 15.84 & 7.23 & 8.57 & 0.68 \\
\hline Electrical equipment (335) & Eleq & 0.13 & 8.43 & -2.11 & 8.82 & 0.69 \\
\hline Transportation equip. (336) & Tran & 2.26 & 13.94 & 1.25 & 10.86 & 0.76 \\
\hline Furniture (337) & Furn & -3.21 & 5.65 & -2.97 & 10.32 & 0.75 \\
\hline
\end{tabular}

Note: The Trans-Pacific (TP) region, as used in this study, covers a total of eight countries (Canada, Japan, South Korea, Mexico, Malaysia, Peru, Thailand, and Taiwan). The number in the parentheses represents the NAICS code for each sector. The means and standard deviations are expressed in terms of annual growth rates (\%). The correlation coefficient is the correlation between the corresponding same sectors for the US and the TP region. 
Table 3: The Identification Strategy of Shocks

\begin{tabular}{|c|c|c|}
\hline & $\begin{array}{l}\text { Abbrev } \\
\text {-iation }\end{array}$ & $\begin{array}{l}\text { US sectors that do not respond contemporaneously to TP } \\
\text { shocks ("slow-moving variables") }\end{array}$ \\
\hline TP overall & IP & Bev, Paper, Nmet, Furn \\
\hline TP Mining & Min & $\begin{array}{l}\text { Wood }(0.0 \%) \text {, Plas }(0.0 \%) \text {, Fmet }(0.0 \%) \text {, Mach }(0.0 \%) \text {, Comp }(0.0 \%) \text {, Eleq } \\
(0.0 \%) \text {, Tran }(0.0 \%) \text {, Furn }(\mathbf{0 . 0} \%) \text {, Food }(0.2 \%) \text {, Bev } \mathbf{( 0 . 2 \% )} \text {, Paper }(0.3 \%)\end{array}$ \\
\hline TP Food & Food & $\begin{array}{l}\text { Min }(0.0 \%) \text {, Wood }(\mathbf{0 . 0} \%) \text {, Plas }(0.0 \%) \text {, Nmet }(0.0 \%) \text {, Pmet }(0.0 \%) \text {, Fmet } \\
(0.0 \%) \text {, Mach }(0.0 \%) \text {, Comp }(0.0 \%) \text {, Eleq }(0.0 \%) \text {, Tran }(0.0 \%) \text {, Furn }(\mathbf{0 . 0} \%) \text {, } \\
\text { Petro }(0.1 \%) \text {, Paper }(0.3 \%)\end{array}$ \\
\hline TP Bev./tobacco & Bev & Same as for Food \\
\hline TP Wood & Wood & $\begin{array}{l}\text { Min }(\mathbf{0 . 3 \%}) \text {, Petro }(0.0 \%) \text {, Fmet }(0.7 \%) \text {, Eleq }(\mathbf{0 . 7 \%}) \text {, } \\
\text { Nmet }(0.8 \%)\end{array}$ \\
\hline TP Paper & Paper & Min $(0.2 \%)$, Petro (0.2\%), Wood (0.5\%) \\
\hline TP Petroleum/coal & Petro & Comp (0.6\%), Furn $(0.4 \%)$ \\
\hline TP Chemical & Chem & Furn $(\mathbf{0 . 4 \%})$, Wood $(\mathbf{0 . 6 \%})$, Pmet $(0.7 \%)$, Eleq $(0.8 \%)$ \\
\hline TP Plastic/rubber & Plas & Petro $(0.2 \%)$, Wood $(0.5 \%)$ \\
\hline TP Nonmetal. min. & Nmet & Furn $(0.7 \%)$, Paper $(0.8 \%)$ \\
\hline TP Primary metals & Pmet & $\begin{array}{l}\text { Wood }(\mathbf{0 . 0} \%) \text {, Paper }(0.0 \%) \text {, Petro }(0.0 \%) \text {, Chem }(0.0 \%) \text {, Nmet }(0.3 \%) \text {, Plas } \\
(\mathbf{0 . 6 \% )}\end{array}$ \\
\hline TP Fabricated metal & Fmet & Petro $(0.2 \%)$, Wood $(1.1 \%)$ \\
\hline TP Machinery & Mach & Petro $(0.1 \%)$, Furn $(\mathbf{0 . 1 \%})$, Nmet $(0.3 \%)$, Wood $(\mathbf{0 . 4 \% )}$, Comp $(0.7 \%)$ \\
\hline $\begin{array}{l}\text { TP Computer/ } \\
\text { electronics }\end{array}$ & Comp & $\begin{array}{l}\text { Petro }(0.1 \%) \text {, Min }(\mathbf{0 . 2} \%) \text {, Wood }(0.4 \%) \text {, Nmet }(0.7 \%) \text {, } \\
\text { Furn }(\mathbf{0 . 7 \%})\end{array}$ \\
\hline TP Electrical equip. & Eleq & Petro $(0.1 \%)$, Min $(\mathbf{0 . 2} \%)$, Furn $(\mathbf{0 . 2} \%)$, Nmet $(0.3 \%)$, Paper $(0.9 \%)$ \\
\hline TP Transp. equip. & Tran & $\begin{array}{l}\text { Petro }(0.0 \%) \text {, Eleq }(0.1 \%) \text {, Furn }(0.1 \%) \text {, Wood }(0.2 \%) \text {, Plas }(0.2 \%) \text {, Nmet } \\
(0.2 \%) \text {, Min }(0.3 \%) \text {, Pmet }(0.3 \%) \text {, Comp }(0.3 \%) \text {, Chem }(0.3 \%) \text {, Fmet }(0.5 \%) \text {, } \\
\text { Food }(\mathbf{0 . 8 \%}) \text {, Bev (0.8\%) }\end{array}$ \\
\hline TP Furniture & Furn & $\begin{array}{l}\text { Min }(0.0 \%) \text {, Food }(\mathbf{0 . 0} \%) \text {, Bev }(\mathbf{0 . 0} \%) \text {, Paper }(0.0 \%) \text {, Petro }(0.0 \%) \text {, Chem } \\
(0.0 \%), \text { Nmet }(0.0 \%), \text { Pmet }(0.0 \%), \\
\text { Fmet }(0.0 \%) \text {, Eleq }(0.1 \%)\end{array}$ \\
\hline
\end{tabular}

Note: The Trans-Pacific (TP) region, as used in this study, covers a total of eight countries (Canada, Japan, South Korea, Mexico, Malaysia, Peru, Thailand, and Taiwan). For the FAVAR analysis, the slow-moving variables are selected on the basis of the trade statistics obtained from Europa World Plus, 2013 or the input-output Use Table (Producer Price) provided by the US Bureau of Labor Statistics, 2012. For the different sectors, if sector $A$ sells less than $1 \%$ of its product to sector $B$, then sector $B$ is assumed not to respond to shocks in sector $A$ within the same month. For each sector we select at least two US sectors in the identification process. The sectors in bold letters are those used as slow-moving variables in the later robustness checks. 
Table 4: The Percentage Explained by the Two Principal Components for the US and Trans-Pacific region

\begin{tabular}{l|cc}
\hline & US & TP \\
\hline Overall Industrial Production & 0.90 & 0.96 \\
\hline Mining & 0.47 & 0.51 \\
Food & 0.07 & 0.11 \\
Beverage/tobacco & 0.07 & 0.18 \\
Wood & 0.61 & 0.46 \\
Paper & 0.73 & 0.90 \\
Petroleum/coal & 0.05 & 0.06 \\
Chemical & 0.60 & 0.88 \\
Plastic/rubber & 0.80 & 0.94 \\
Nonmetallic minerals & 0.75 & 0.92 \\
Primary metals & 0.86 & 0.93 \\
Fabricated metals & 0.87 & 0.91 \\
Machinery & 0.87 & 0.89 \\
Computer/electronics & 0.66 & 0.80 \\
Electrical equipment & 0.69 & 0.87 \\
Transportation equipment & 0.72 \\
\hline Average of the 16 sectors & 0.76 \\
& & 0.68 \\
\hline
\end{tabular}

Note: Two principal components are extracted to calculate the fitted variable. The percentage explained is the variance of the fitted variable divided by the variance of the original variable. Each series is standardized before applying the principal component analysis. The sample period is 2001:1-2013:8. 
Table 5: The Responsiveness and the Speed of the Impulse Response of the Overall US Output to

Trans-Pacific Sectoral Shocks

\begin{tabular}{l|cc}
\hline Shocks & Responsiveness & Speed of response \\
\hline TP Mining & -0.10 & 0.77 \\
TP Food & 0.41 & 0.77 \\
TP Beverage/tobacco & 0.09 & 0.47 \\
TP Wood & -0.80 & 1.63 \\
TP Paper & 0.79 & 1.44 \\
TP Petroleum/coal & 1.11 & 2.14 \\
TP Chemical & 0.68 & 1.26 \\
TP Plastic/rubber & 0.92 & 2.17 \\
TP Nonmetallic minerals & 0.65 & 1.31 \\
TP Primary metals & 0.58 & 1.74 \\
TP Fabricated metals & 1.75 & 5.68 \\
TP Machinery & 0.83 & 3.12 \\
TP Computer/electronics & 0.54 & 0.85 \\
TP Electrical equipment & 0.51 & 3.23 \\
TP Transportation equipment & 0.59 & 1.29 \\
TP Furniture & 0.51 \\
\hline TP Overall & 0.53 \\
\hline
\end{tabular}

Note: The Trans-Pacific (TP) region, as used in this study, covers a total of eight countries (Canada, Japan, South Korea, Mexico, Malaysia, Peru, Thailand, and Taiwan). The responsiveness is calculated by dividing the accumulated response of the US overall industrial production in the first six months by the accumulated response of the Trans-Pacific sectoral output over the same period. The speed of response is calculated by dividing the average response of the US overall industrial production in the first six months by the average of the response over the seventh through twelfth month. The size of the innovation is set to one standard deviation of the Trans-Pacific sectoral industrial production. 
Figure 1: Graphs of the Growth Rates of Output Measures (Overall and Sectors) in the US and Trans-Pacific Region

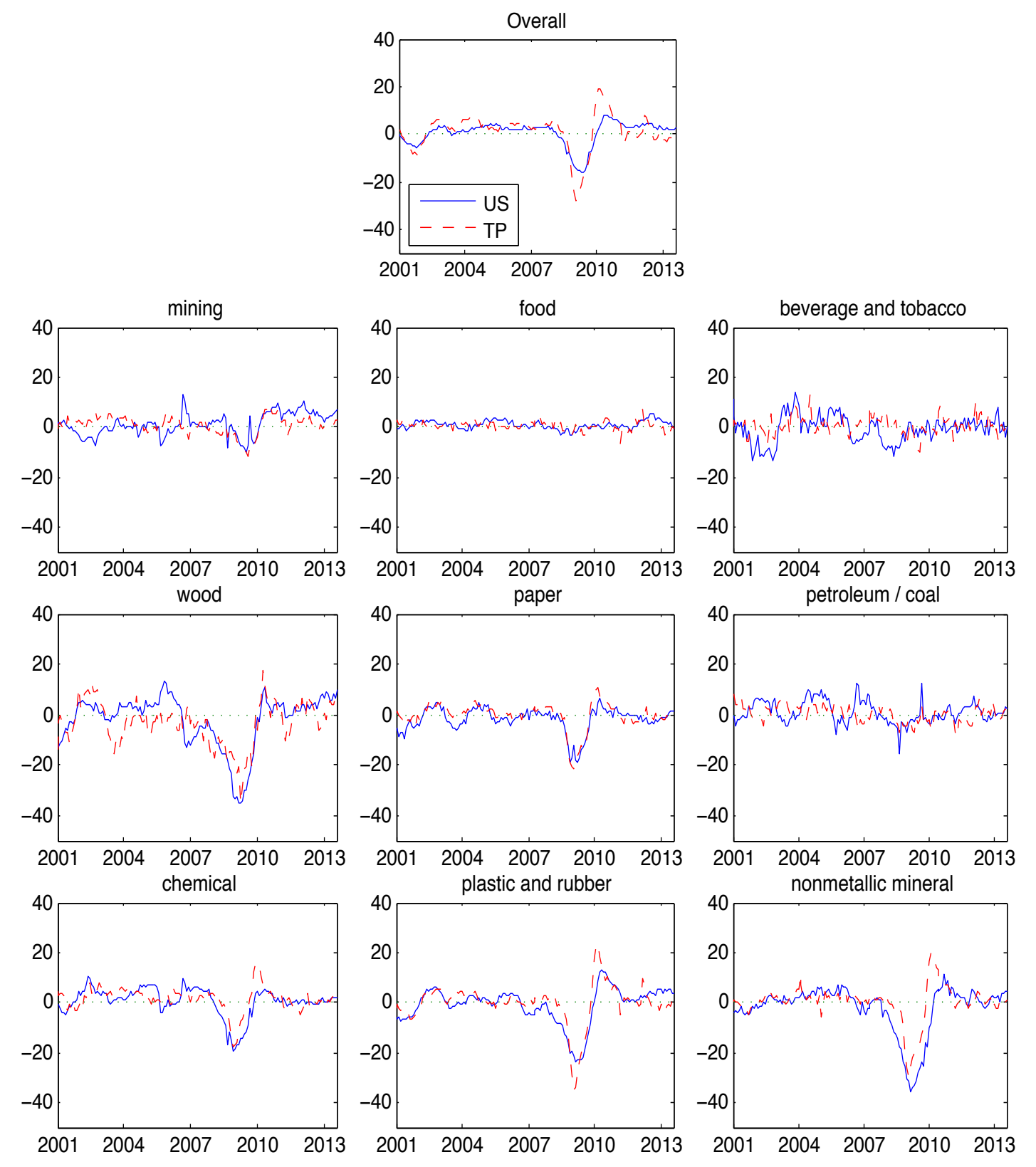


Figure 1: Graphs of the Growth Rates of Output Measures (Overall and Sectors) in the US and Trans-Pacific Region (continued from previous page)
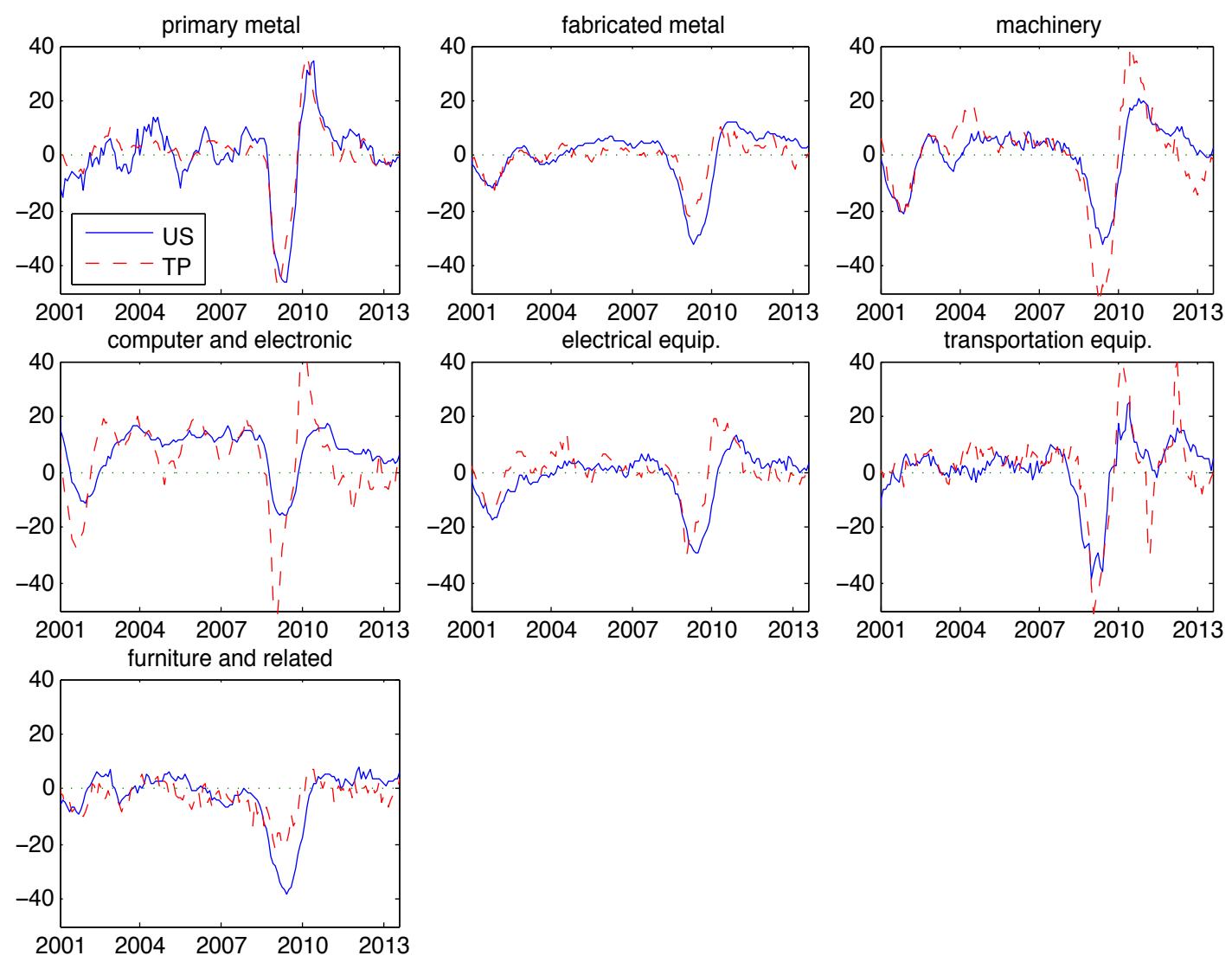

Note: The Trans-Pacific (TP) region, as used in this study, covers a total of eight countries (Canada, Japan, South Korea, Mexico, Malaysia, Peru, Thailand, and Taiwan). Each panel presents the time series of the industrial production growth rates for the US (solid line) and the TP region (dashed line) overall and for sixteen different sectors. The sample period is 2001:1 - 2013:08. The growth rates are in annual percentage terms. 
Figure 2: Factor Loadings

(a) Sorted by Region/Countries

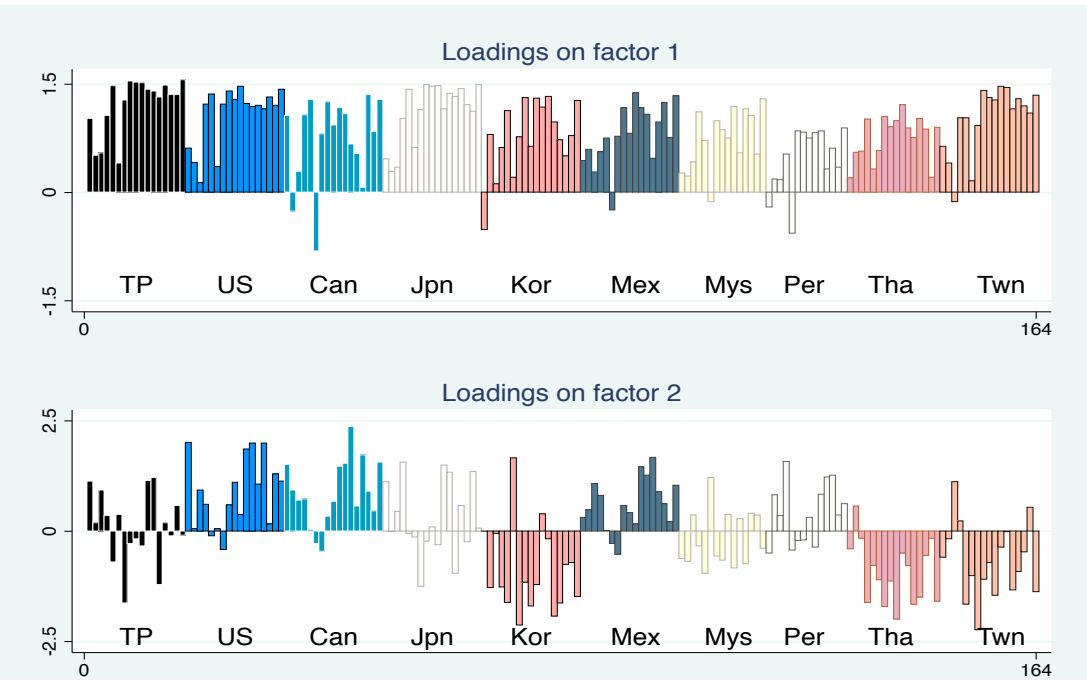

(b) Sorted by Sectors/Overall Output

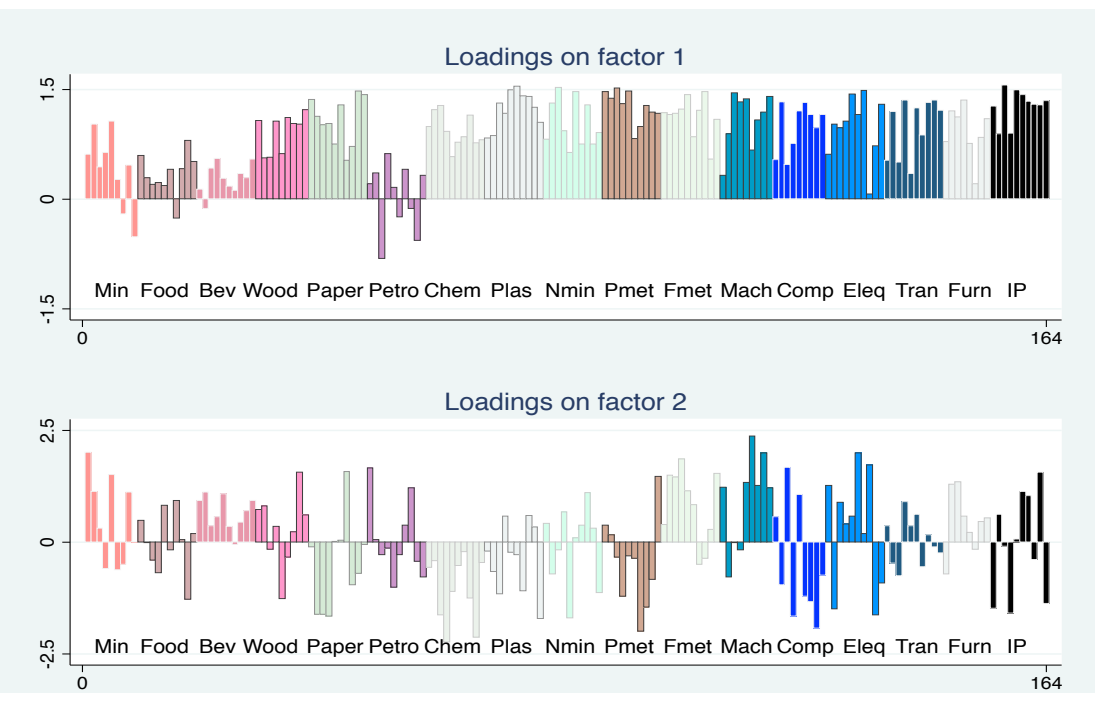

Note: The Trans-Pacific (TP) region, as used in this study, covers a total of eight countries (Canada, Japan, South Korea, Mexico, Malaysia, Peru, Thailand, and Taiwan). The panels present the values of factor loadings with the height of the individual bar representing the value of the coefficient in the factor loadings matrix. The two panels represent exactly the same loadings, but organized in different groupings. The top panel presents the values of factor loadings ordered by country. The first group (TP) represents the loadings for the entire Trans-Pacific region. The bottom panel shows the factor loadings ordered by sector. The last group (IP) represents the loadings for the overall industrial production for each country. All series are standardized before applying the principal component analysis. 
Figure 3: The Impulse Responses of US Output (Overall and by Sectors) to an Overall Trans-Pacific Output Shock
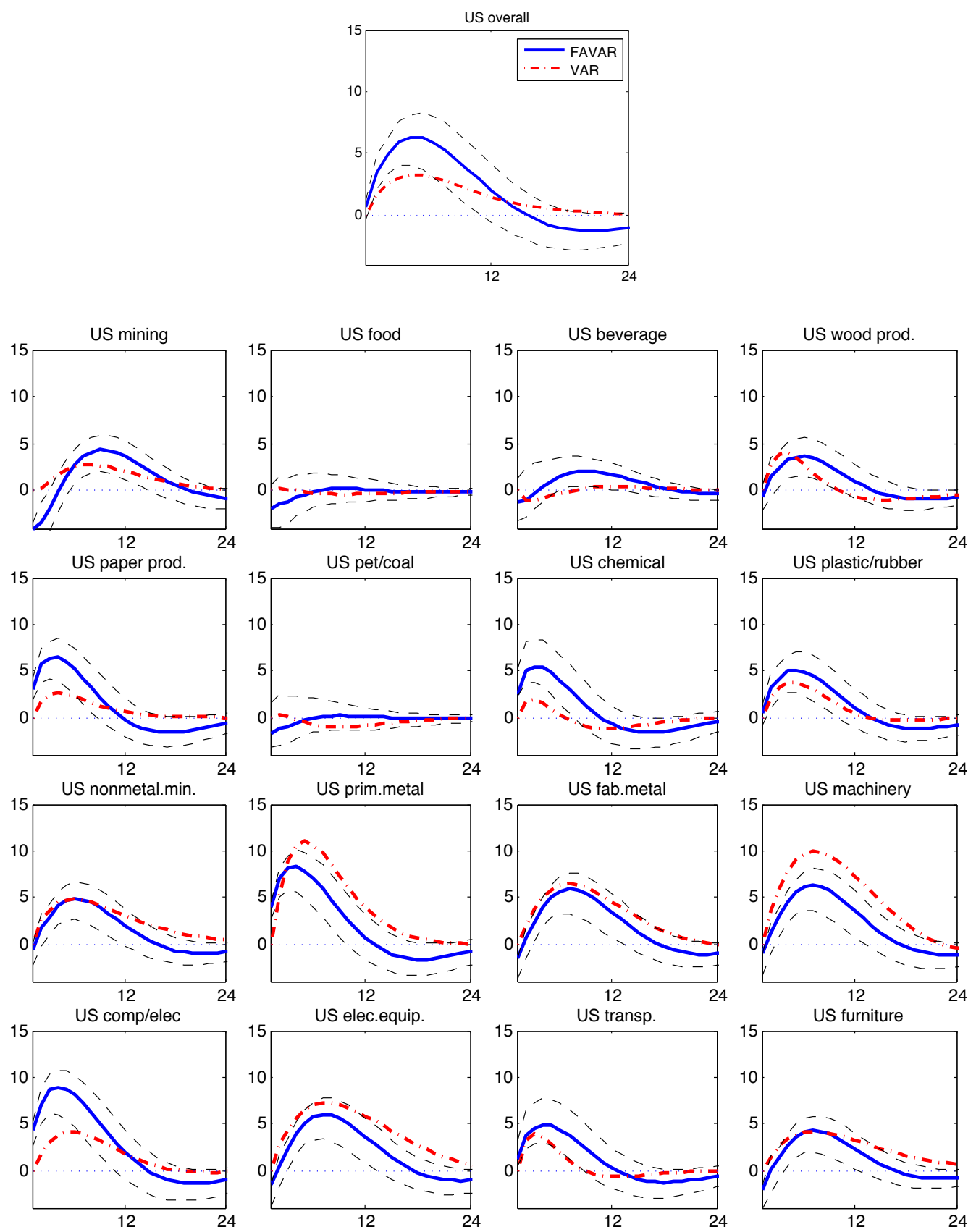

Note: The solid line in each panel presents the impulse response of US industrial production to a one standard deviation shock in the Trans-Pacific overall industrial production using a factor augmented vector autoregression (FAVAR). The dashdotted line presents the same impulse response using a simple bivariate vector autoregression (VAR). The dashed lines represent the $95 \%$ confidence intervals associated with the FAVAR impulse response. All variables are expressed in terms of growth rates (\%). The confidence intervals are calculated using the two-step bootstrap method of Kilian (1998). 
Figure 4: The Impulse Responses of Overall US Output to Trans-Pacific Sectoral Output Shocks
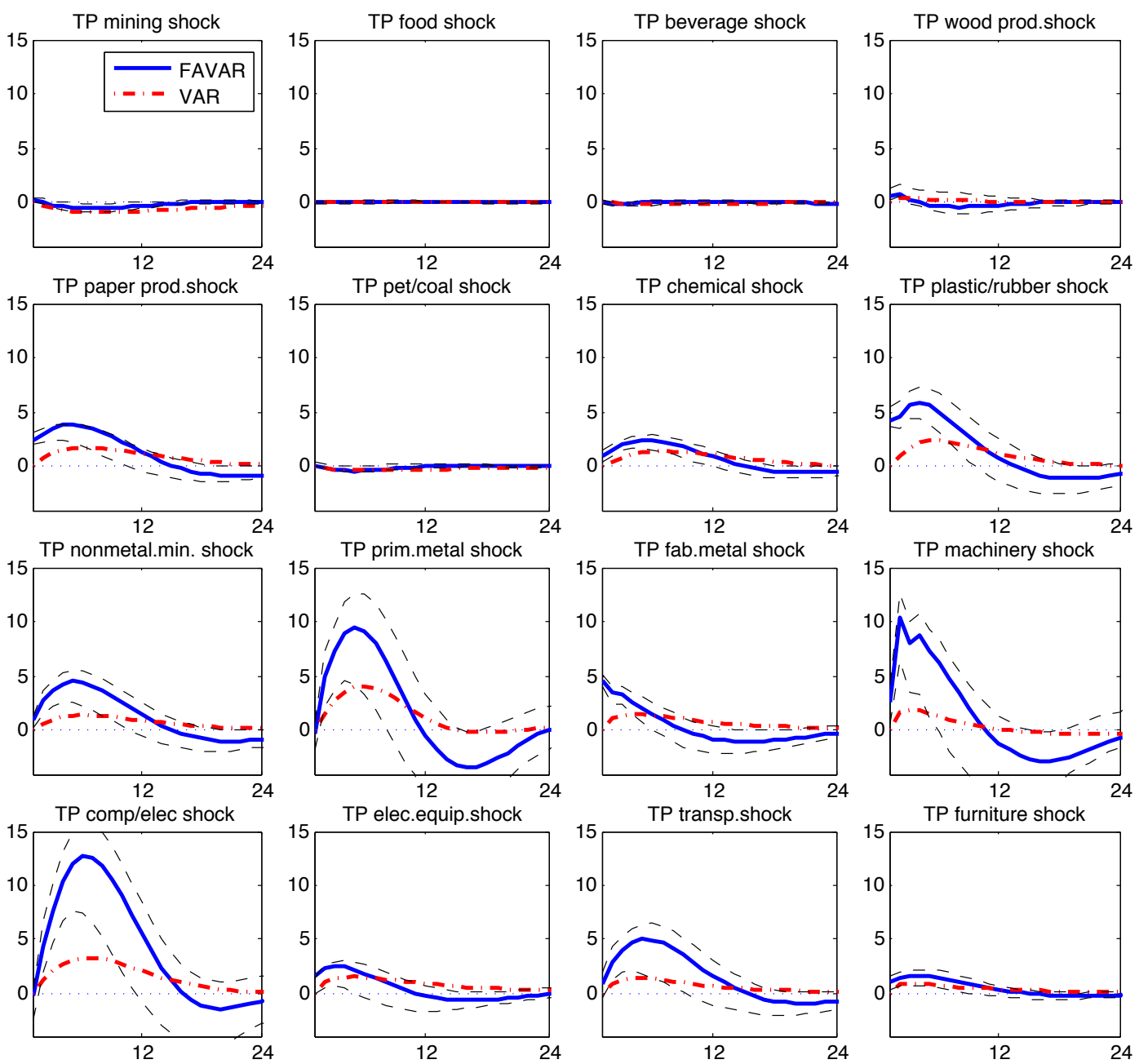

Note: The solid line in each panel presents the impulse response of US overall industrial production to a one standard deviation shock in the Trans-Pacific sectoral industrial production using a factor augmented vector autoregression (FAVAR). The dash-dotted line presents the same impulse response using a simple bivariate vector autoregression (VAR). The dashed lines represent the $95 \%$ confidence intervals associated with the FAVAR impulse response. All variables are expressed in terms of growth rates (\%). The confidence intervals are calculated using the two-step bootstrap method of Kilian (1998). 
Figure 5: The Impulse Responses of US Overall and Sectoral Outputs to Selected

\section{Trans-Pacific Sectoral Output Shocks}
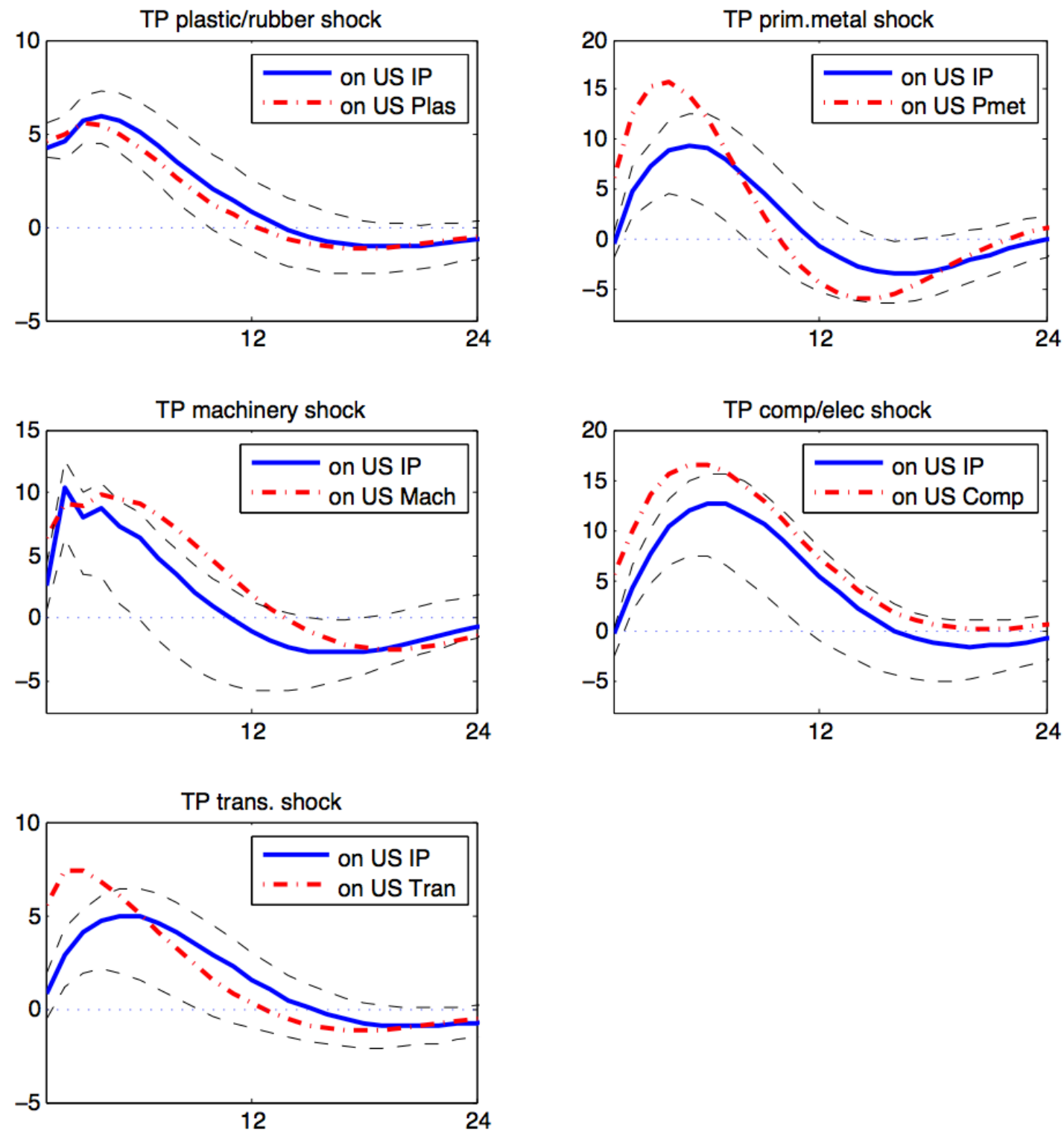

Note: The Trans-Pacific (TP) region, as used in this study, covers a total of eight countries (Canada, Japan, South Korea, Mexico, Malaysia, Peru, Thailand, and Taiwan). The solid line in each panel presents the impulse response of US overall industrial production to a one standard deviation shock in the Trans-Pacific sectoral industrial production using a factor augmented vector autoregression (FAVAR). The dash-dotted line presents the impulse response of the US sector, which belongs to the same sector as the Trans-Pacific sector in which the shock occurs. The dashed lines represent the $95 \%$ confidence intervals associated with the FAVAR impulse response. All variables are expressed in terms of growth rates (\%). The confidence intervals are calculated using the two-step bootstrap method of Kilian (1998). 
Figure 6: Impulse Responses of US Output (Overall and Mining) to an Overall Trans-Pacific Output Shock with Oil Price (Exogenous) and/or Chinese Industrial Production (Endogenous)

US Overall Industrial Production
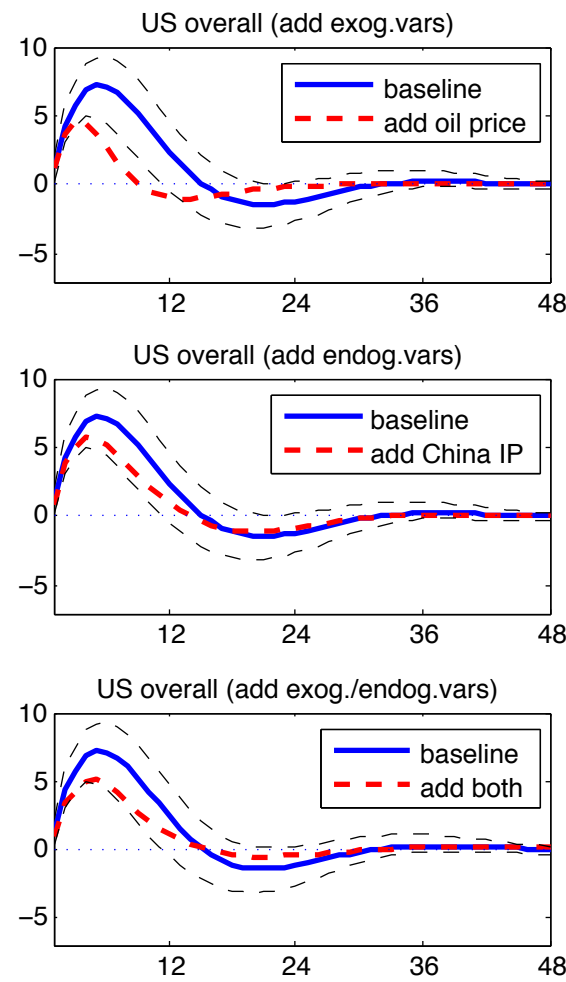

US Mining Sector
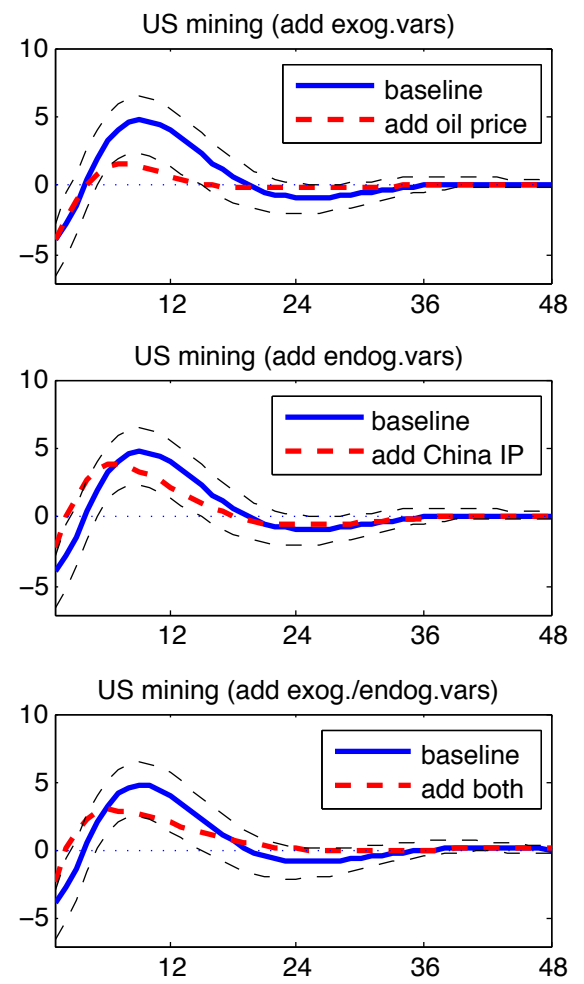

Note: The three panels in the left column present the impulse response of US overall industrial production to a one standard deviation shock on the Trans-Pacific overall industrial production with the addition of oil prices and/or Chinese industrial production. The three panels in the right column present the impulse response of US mining industrial production to the same shocks and added variables. Within each panel, the thick solid line shows the response of the US output in the baseline specification and the thick dashed line shows the response of the US output when additional variables (Chinese industrial production and oil prices) are added to the baseline specification. All variables are expressed in terms of annual growth rates (\%). The confidence intervals (thin dashed lines) for the baseline specification are calculated using two-step bootstrap method of Kilian (1998). 
Figure 7: Impulse Responses of Overall US Output to Foreign Overall Output shocks

TP Output Shock excluding Canada

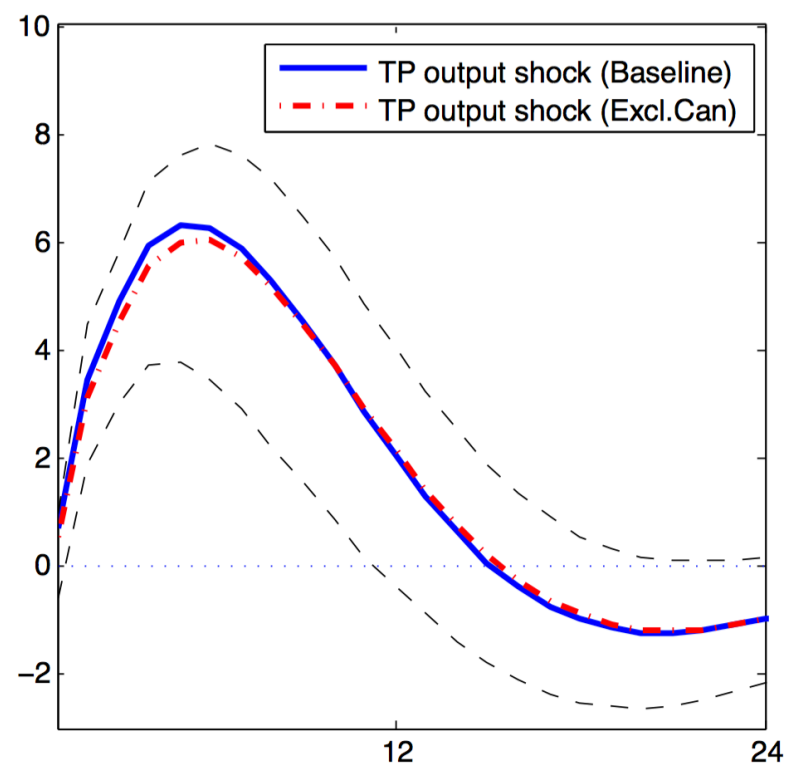

Canadian Output Shock

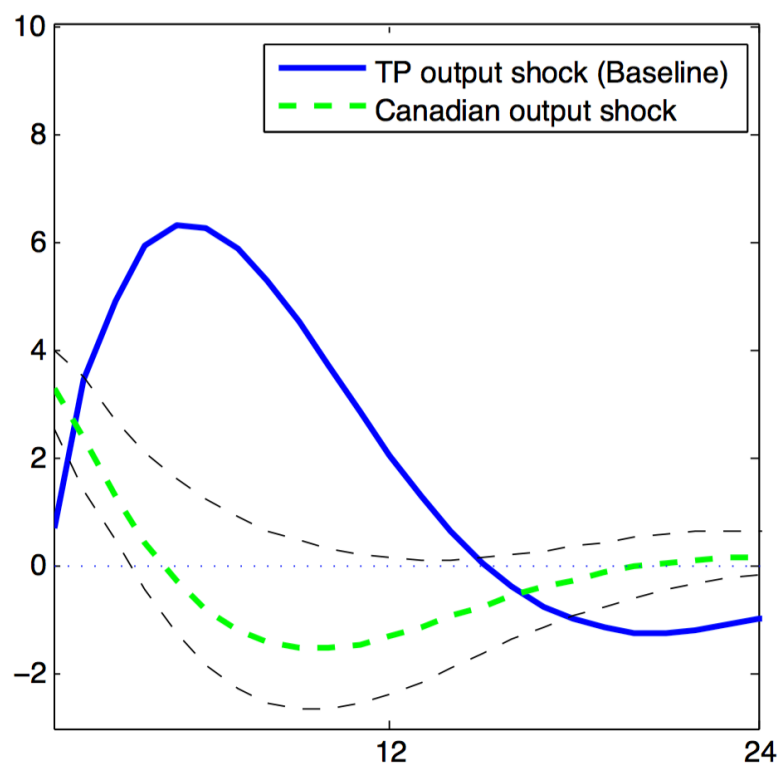

Note: The thick dash-dotted line in the left panel presents the impulse response of US overall industrial production to a shock on the overall industrial production of the Trans-Pacific region excluding Canada. The thick dashed line in the right panel presents the impulse response of US overall industrial production to a shock on the Canadian overall industrial production. The thick solid lines show the response of the US output in the baseline result. The thin dashed lines show the confidence intervals calculated using two-step bootstrap method of Kilian (1998). To facilitate comparison, the shock size is adjusted to the baseline case in Table 2. All variables are expressed in terms of annual growth rates (\%). 